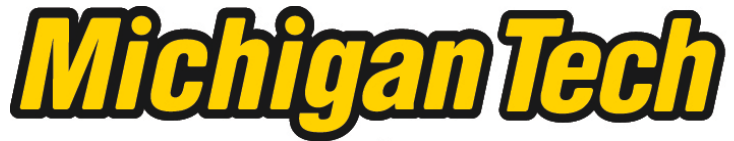 \\ Michigan Technological University Create the Future Digital Commons @ Michigan Tech
}

Dissertations, Master's Theses and Master's Reports - Open

Dissertations, Master's Theses and Master's

Reports

2013

\section{BIOMASS FUEL-BRIQUETTES AND IMPROVED STOVES IN DINSHO, ETHIOPIA}

Brian W. Barbre

Michigan Technological University

Follow this and additional works at: https://digitalcommons.mtu.edu/etds

Part of the Forest Sciences Commons

Copyright 2013 Brian W. Barbre

\section{Recommended Citation}

Barbre, Brian W., "BIOMASS FUEL-BRIQUETTES AND IMPROVED STOVES IN DINSHO, ETHIOPIA", Master's report, Michigan Technological University, 2013.

https://doi.org/10.37099/mtu.dc.etds/609

Follow this and additional works at: https://digitalcommons.mtu.edu/etds

8 Part of the Forest Sciences Commons 
BIOMASS FUEL-BRIQUETTES

AND IMPROVED STOVES IN DINSHO, ETHIOPIA

By

Brian W. Barbre

\begin{abstract}
A REPORT
Submitted in partial fulfillment of the requirements for the degree of MASTER OF SCIENCE
\end{abstract}

In Forest Ecology And Management

MICHIGAN TECHNOLOGICAL UNIVERSITY

2013

C)2013 Brian W. Barbre 
This report has been approved in partial fulfillment of the requirements for the Degree of MASTERS OF SCIENCE in Forest Ecology and Management.

School of Forest Resources and Environmental Science

Report Advisor:

Committee Member:

Committee Member:

Committee Member:

School Dean:
Dr.Blair Orr

Dr. Audrey Mayer

Dr. Susan Martin

Dr. John Gershenson

Dr. Terry Sharik 


\section{Table of Contents}

List of Figures............................................................................... 6

List of Tables.................................................................................. 7

Acknowledgements...................................................................... 8

List of Acronyms.............................................................................. 9

Abstract.............................................................................................. 10

1. Introduction........................................................................... 11

2. General Background................................................................ 13

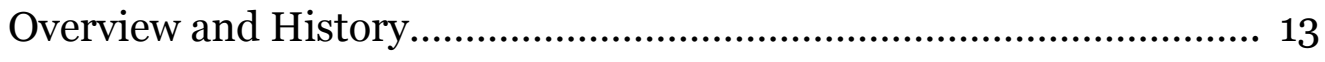

Climate and Topography .................................................................. 15

Agriculture and Pastoralism................................................................ 19

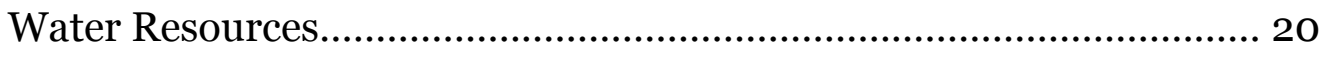

Forests and Ecosystems................................................................ 21

3. Study Site..........................................................................27

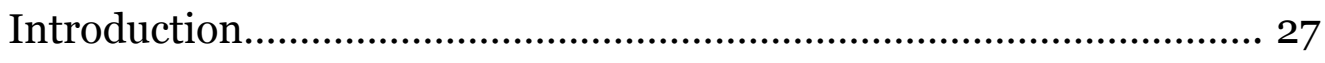

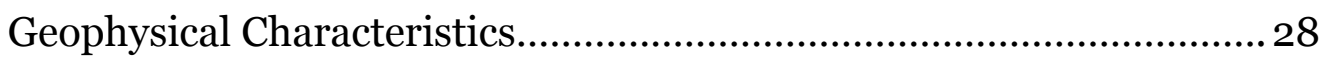

Biodiversity and Bale Mountains National Park...................................... 30

Pastoral History................................................................................. 32

Population Pressure .............................................................................. 33

4. Methods....................................................................................36

5. Project Implementation.............................................................38 
Introduction

Step 1: Fuel Briquette Research and Development............................... 41

Step 2 A: Briquette Materials Collection and Sourcing...........................54

Step2 B: Stove Materials Collection and Sourcing................................. 55

Step 3: Association and Group Establishment........................................ 56

Step 4 A and B: Briquette and Stove Theory and Training.....................57

Step 5 A and B: Materials Processing and Preparation........................... 57

Step 6 A and B: Briquette and Stove Manufacture Training.................. 57

Step 7: In-home Trials, Period 1..................................................... 58

Step 8: In-home Trials, Period 2.......................................................... 59

Step 9 Analysis of Results....................................................................6 60

6. Discussion.................................................................. 61

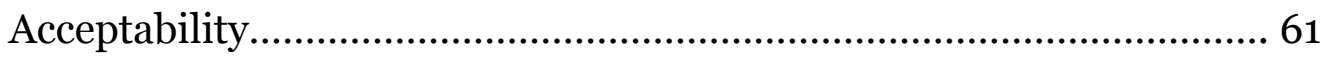

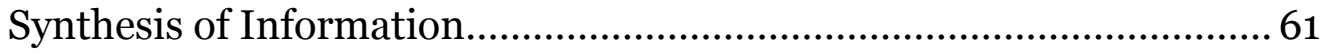

Perceived Barriers, the Ethiopian Context............................................... 62

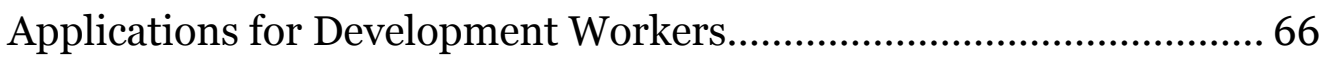

Fuel Briquette Project Recommendations.............................................. 69

Cost Effectiveness.............................................................................. 72

Stove Project Recommendations............................................................ 73

Respondent Creativity......................................................................... 74

7. Conclusion.......................................................................... 76

General Framework for Briquette and Stove Development................... 77 


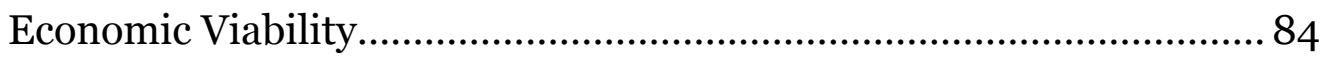

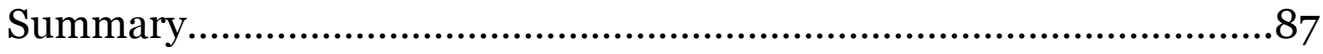

8. Works Cited..........................................................89

Appendix 1.........................................................................94

Appendix 2..............................................................................95

Appendix 3......................................................................98 


\section{List of Figures}

Figure 2.1. $\quad$ Map of Ethiopia and surrounding countries................................ 13

Figure 2.2. Administrative and topographic map...................................... 18

Figure 2.3. Eucalyptus plantation on a degraded hillside...............................26

Figure 3.1. Location of Bale Moiuntains National Park and Dinsho town...... 27

Figure 3.2. Primary conservation endemic and endangered species;

Left: Mountain nyala, Tragelaphus buxtoni Right: Ethiopian

wolf, Canis simensis.

Figure 3.3. Degrade juniper forest, converted to barley............................... 35

Figure 3.4. The present line of the illegal harvest of Erica species

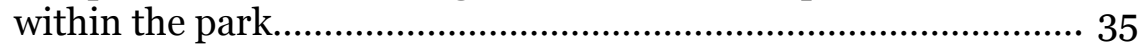

Figure 5.1. Briquette press in use during a training session..........................38

Figure 5.2. Flowchart of desired project framework...................................... 39

Figure 5.3. Amended flow chart showing actual steps taken.........................40

Figure 5.4. Left; Materials that have passed the squeeze and saltshaker test. Right; Paper that has been soaked in water and pulped, ready for mixing. 45

Figure 5.5. Left, preliminary burn test. Right, water-boiling test....................45

Figure 5.6. Traditional two-chambered charcoal stove...................................48

Figure 5.7. Top, stove cross section. Bottom shows two assembled stoves.....50

Figure 5.8. Stove molds and products.................................................... 51

Figure 5.9. Clay worker from Goba with one and two-piece stove liners..........51

Figure 5.10. Wet ceramic from the mold resting on metal liner........................53

Figure 7.1. Recommended project framework............................................78 


\section{List of Tables}

Table 2.1. Major agro-climactic zones and their characteristics.............16

Table 2.2. Ecological and vegetational zonation schemes and their Altitudes................................................................................. 23

Table 5.1. Number of pitchers used per ingredient for trials and test results................................................................................43

Table 6.1. $\quad$ Pricing responses for willingness to pay for briquette and stoves and estimated birr saved in fuelwood reduction.........73 


\section{Acknowledgements}

This report would not have been possible if were not for the assistance of multiple people, organizations, friends and family members. First I must thank my advisor Blair Orr. When my data collection took a turn for the worst he encouraged me to continue. Sure enough he helped me make something out of what I felt was nothing. Considerable thanks is due to the members of my graduate committee; Susan Martin, Audrey Mayer and John Gershenson. With their assistance I was able to coax a deeper meaning out of my experience that helped build this report.

Without Peace Corps Ethiopia staff and teachers I would not have survived in Ethiopia. With their support, language and cultural facilitation I was able to truly become a member of the Dinsho community. My counterpart organizations, the Ethiopian Wolf Conservation Program and the Frankfurt Zoological Society gave me not only a house but a home, friendship, sanity and work support that made this possible. Thanks Chris Gordon, Anne-Marie Stewart, Anouska Kinahan, Thadaigh Baggallay, and Zegeye Kibret. My friends in Dinsho are too many to list but they were my teachers, friends and sounding boards for all of my ideas, crazy or not.

Finally I must thank my friends and family back at home who supported me through this long trip. I owe you all my deepest gratitude. 


\section{List of Acronyms}

$\begin{array}{ll}\text { BMNP } & \text { Bale Mountains National Park } \\ \text { CASTLE } & \begin{array}{l}\text { Center for Alternative and Sustainable Livelihood } \\ \text { Enhancement }\end{array} \\ \text { EWCP } & \text { Ethiopian Wolf Conservation Program } \\ \text { FZS } & \text { Frankfurt Zoological Society } \\ \text { GIZ } & \text { German Society for International Cooperation } \\ \text { GMP } & \text { General Management Plan } \\ \text { masl } & \text { Meters above sea level } \\ \text { NGO } & \text { Non-governmental organization } \\ \text { NTFP } & \text { Non-timber forest product } \\ \text { OFWE } & \text { Oromia Forest and Wildlife Enterprise } \\ \text { TLF } & \text { The Legacy Foundation } \\ \text { UNESCO } & \text { United Nations Educational, Scientific and Cultural } \\ & \text { Organization }\end{array}$




\begin{abstract}
This report is a study of the development and implementation of a biomass fuel briquette and improved stove project in the highlands of Ethiopia. The primary goal of the project was to determine if the introduction of an improved stove would affect the acceptability of fuel briquettes. The secondary goal was to establish briquette and improved stove manufacturing associations in Dinsho and Rira towns. Two problems encountered during the project were cultural differences in material valuation, and difficulty working with local administrative frameworks and multi-organization communication difficulties. Both briquettes and improved stoves received positive feedback from respondents. Survey data indicated that a price of 0.75 Ethiopian birr per briquette would make them a competitive fuel source against fuelwood. Recommendations for feedstock sourcing and supply, capital investment, labor reduction, estimating cost effectiveness, appropriate technology design, development work setbacks, and valuation paradigms for fuel briquette, improved stove, and development work projects.
\end{abstract}




\section{Chapter 1: Report Introduction}

As a Peace Corps Volunteer I was posted in the Ethiopian highlands and assigned to work in partnership with the Ethiopian Wolf Conservation Program (EWCP). I reached out to other non-governmental organizations (NGOs), one of which was the Frankfurt Zoological Society (FZS). They help manage the Bale Mountains National Park (BMNP) operations by writing and implementing the BMNP General Management Plan (GMP). After discussing project ideas I visited the Center for Alternative and Sustainable Technologies for Livelihood Enhancement (CASTLE). In this compound FZS was engaged in improved technologies that are compatible with both conservation and development objectives, including low cement building blocks and Mirt stoves (wood saving stoves for making the traditional flat bread injera), and biomass fuel briquettes. FZS had reallocated their resources to other Park management issues and infrastructure projects so they offered me the fuel briquette program.

The purpose of this report is to discuss the implementation of a fuel briquette and improved stove project in the highlands of Ethiopia and the changes made throughout each phase, the steps and methods I had envisioned following, and their relation to what actually happened during 
implementation. Chapter two is a general introduction to Ethiopia and provides pertinent background information for the study. Chapter three introduces the study site's environmental, political and socio-cultural influences and my motivation for choosing to focus on biomass briquettes and improved stoves.

Chapter four is a brief description of data collection and analysis methods. Chapter five follows the step by step implementation of the project according to the ideal project framework flowchart. The ideal project framework flowchart is compared to an amended flowchart of the actual events as they took place and discrepancies between the two are discussed. Chapter six is the discussion of the lessons learned through synthesis of information, community acceptability, perceived barriers to the project, applications and recommendations for future projects and development workers, cost effectiveness and respondent creativity. Chapter seven contains concluding thoughts about project activities and the experience. 


\section{Chapter 2: General Background}

\section{Overview and History}

The Federal Democratic Republic of Ethiopia is located in the Horn of Africa from $3^{\circ} 30^{\prime \prime}$ to $15^{\circ} \mathrm{N}$ and $33^{\circ}$ to $48^{\circ} \mathrm{E}$. It is a relatively large country with an area of $1,104,300 \mathrm{~km}^{2}$, roughly twice the size of Texas (C.I.A. 2013). After the separation of Eritrea in 1991 Ethiopia became a landlocked nation (C.I.A. 2013) and now shares its borders with Sudan and South Sudan to the west, Kenya to the south, Somalia to the east-southeast, Djibouti to the east and Eritrea to the northeast (Figure 2.1).

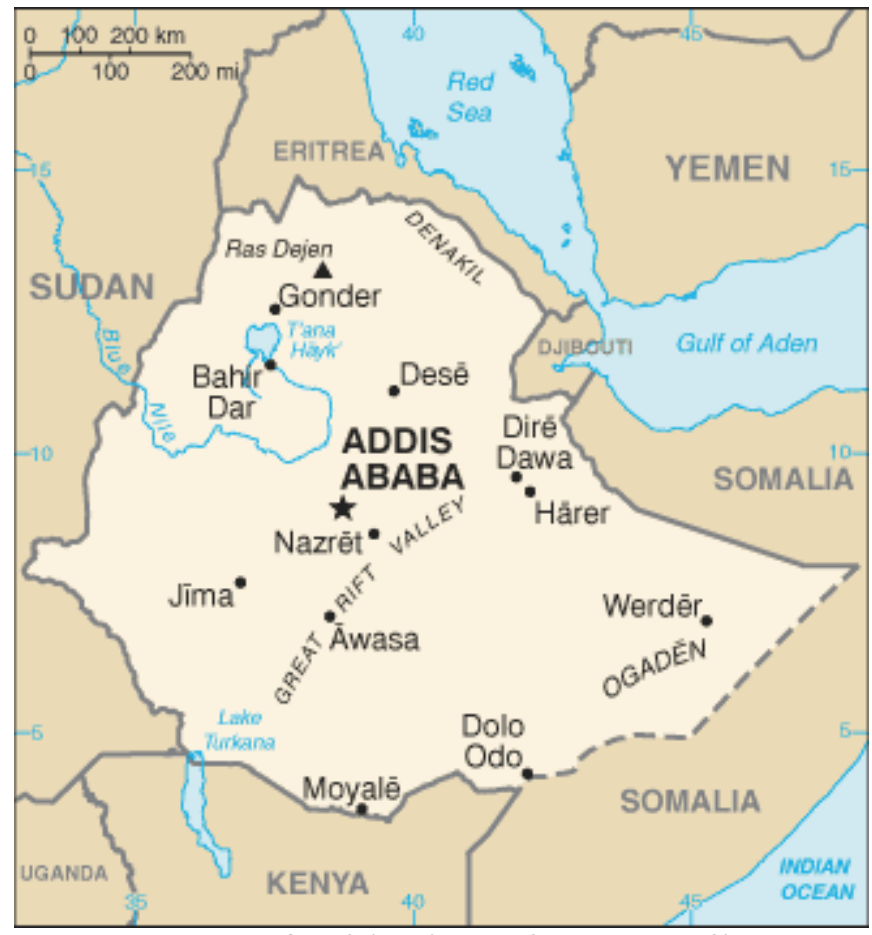

Figure 2.1: Map of Ethiopia and surrounding countries (Source: C.I.A. 2013) Appendix 1, permission for use. 
As of 2012 the population of Ethiopia was 91,195,675 with an annual growth rate of $2.9 \%$ (C.I.A. 2013). Ethiopia is comprised of over eighty different cultural groups, each with, and largely defined by, its own language. There are 11 large administrative regions or states in Ethiopia. Addis Ababa (the capital), Harar and Dire Dawa are individual cities that are large enough to be classified as city states, followed by Gambella, Benishangul, Southern Nations Nationalities Peoples Region, Somali, Afar, Oromia, Amhara, and Tigray, of which the last three are the largest by population and percent spoken language. The political structure breaks down into smaller hierarchical demarcations from region or state to zone, woreda and kebele as the smallest administrative level.

Ethiopia is uncommon in that it was never colonized by a foreign power and maintained self rule except during the short Italian occupation between 1935 and 1941 (Ofacnsky and Berry 1991). Because of its long autonomous political independence, its cultural traditions are rooted in more than two millennia of history, claiming a dynasty that goes back as far as the Queen of Sheba's visit to the court of Solomon in the Old Testament (Hess 1970). The last member of this biblical line who ruled was Emperor Haile Selassie, crowned in 1930. His reign and Ethiopian independence was tested in 1935 by an invasion of Italian troops stationed in Eritrea and Italian Somaliland (Ofacnsky and Berry 1991). Once Italy joined World War II the British became involved in the ground war with the goal of routing out Italian occupation in 
the Horn of Africa. Halie Selassie reclaimed power in 1941 and retained control till 1974 when the Derg, a military regime, took control. The Derg held control until 1987 (Ofacnsky and Berry 1991).

\section{Climate and Topography}

The climate is tropical monsoon where altitudinal and topographical variation creates different microclimates ranging from hot, sub-sea level deserts with active volcanic activity to cool, wet highlands (Seleshi and Zanke 2004). Three seasons are delineated by weather patterns. The main rainy season runs from June to September (Kiremt), the winter or dry season from October to December or January (Bega) and the short rainy season from February or March to May (Belg) (Seleshi and Zanke 2004). The boundary between Belg and Kiremt can be hard to distinguish in years of heavy rain. The length and severity of each season varies depending on each location's topographical features and annual climactic influences (Korecha and Barnston 2007). The traditional agro-climactic classification scheme has five zones (Table 2.1). 
Table 2.1: Major agro-climactic zones and their characteristics. (data source Dejene 2003)

\begin{tabular}{|c|c|c|c|c|}
\hline Zone & $\begin{array}{l}\text { Altitude } \\
\text { (meters) }\end{array}$ & $\begin{array}{l}\text { Rainfall } \\
(\mathrm{mm} / \mathrm{yr})\end{array}$ & $\begin{array}{l}\text { Growing season } \\
\text { (days) }\end{array}$ & $\begin{array}{l}\text { Ave. Temp. } \\
\left({ }^{\circ} \mathrm{C}\right)\end{array}$ \\
\hline $\begin{array}{l}\text { Berha } \\
\text { (hot, arid) }\end{array}$ & $<500$ & $<200$ & $0-45$ & $>27.5$ \\
\hline $\begin{array}{l}\text { Kola } \\
\text { (warm, semi-arid) }\end{array}$ & $500-1500$ & $200-800$ & $46-90$ & $20-27.5$ \\
\hline $\begin{array}{l}\text { Weyna Dega } \\
\text { (cool, sub-humid) }\end{array}$ & $1500-2300$ & $800-1200$ & $91-120$ & $16-20$ \\
\hline $\begin{array}{l}\text { Dega } \\
\text { (cool, humid) }\end{array}$ & $2300-3600$ & $900-1200$ & $121-210$ & $11.5^{-16}$ \\
\hline Wurch & $>3600$ & $900-2200$ & $211-365$ & $<11.5$ \\
\hline
\end{tabular}

Ethiopia is often referred to as the rooftop of Africa as it contains an estimated $80 \%$ of the African highlands over 3000 masl. The highlands are divided into two large plateaus to the southeast and northwest by the Central Rift Valley that extends from the Red Sea in the northeast to the southwest, through Kenya (Figure 2.2). The northwestern plateau is bisected into north and south sections by the Blue Nile (Abay) River and has the highest peak, Ras Dashen at 4,620 masl. 
The other notable features of the landscape are the depressions. They are located from the northern edge of the Great or Central Rift Valley to the border with Eritrea. The lowest is the Danakil Depression at 126 meters below sea level (Land Below Sea Level 2013); it is know for its extensive salt beds and mineral pools and active volcanoes (Figure 2.2). 


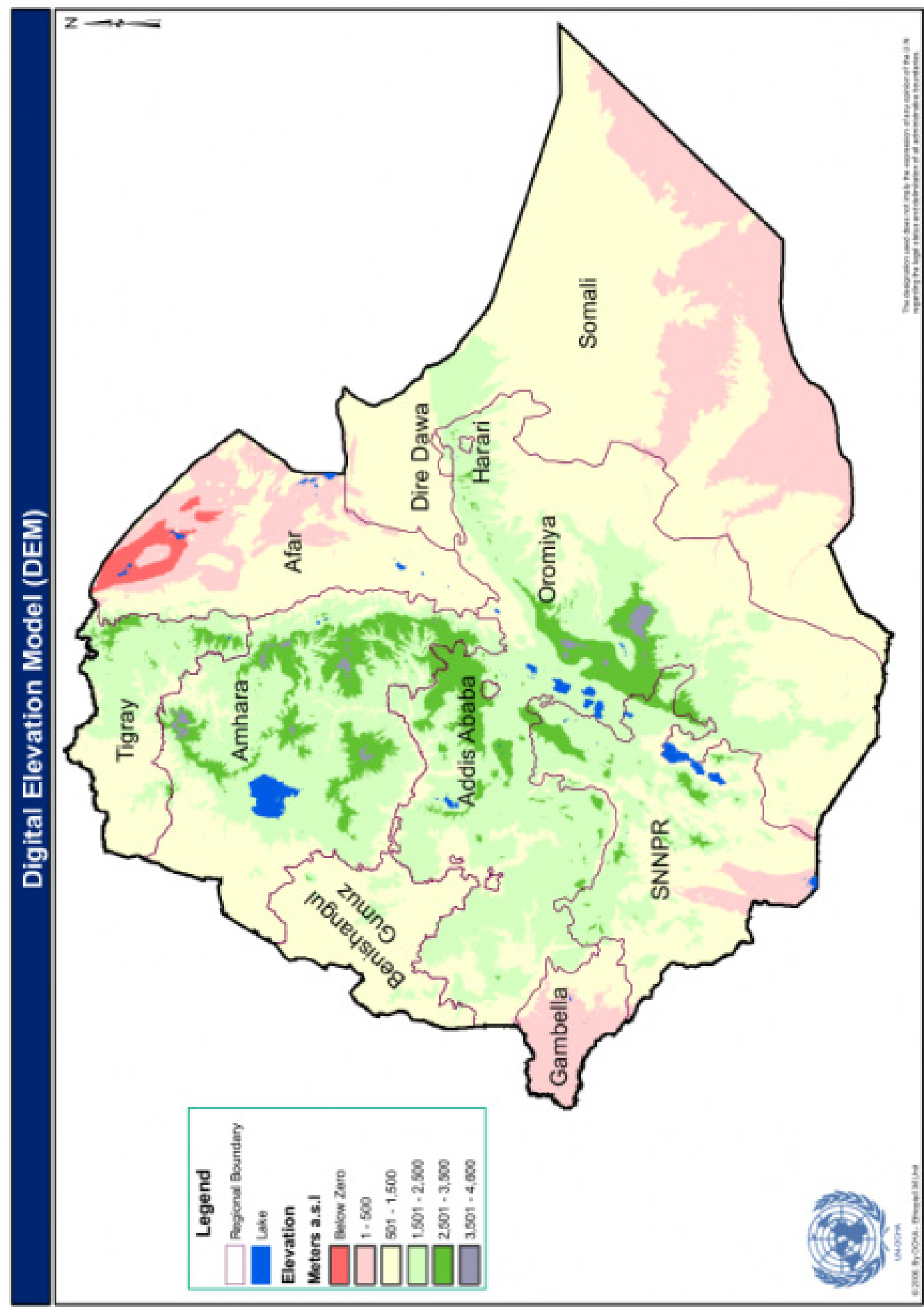

Figure 2.2: Administrative and topographic map. (Source: UN-OCHA, 2006) Appendix 1, permission for use 


\section{Agriculture and Pastoralism}

Ethiopia is an agricultural and agro-pastoral dependent country. These activities provide $41 \%$ of Ethiopia's GDP and $85 \%$ of Ethiopia's employment (C.I.A. 2013). The main agricultural products are cereals, hides, a narcotic plant chat (Catha edulis), cotton, pulses, oil seeds, sugarcane, potatoes, cut flowers, livestock, and coffee. Coffee is the largest crop by value (Taffesse et al. 2011) and number one export, unofficially followed by chat (Feyisa and Aune 2003), and animal hides and meat (Ethiopian Embassy 2010).

As of $200935 \%$ of the country was under agricultural use (World Bank 2013). Cereals are the largest crop by area planted, $73.4 \%$ of the total cultivated area. Teff ( Eragrostis tef) is the most common cereal under cultivation. It is the primary ingredient in the staple flatbread, injera. It is grown in the mid altitudes and shares much of its cultivation area with maize (Zea mays ) and sorghum ( Sorghum bicolor), while wheat ( Triticum aestivum ) and barley (Hordeum vulgare ) dominate highland agriculture (Taffesse et al. 2011).

There are three main problems facing Ethiopian agriculture: central government ownership of all land, antiquated farming methods, and the everincreasing population causing landholding subdivision. The average size of holdings in 2006 of farmers in Oromia, the largest agricultural state, has dropped below one hectare (Van Den Berg and Kumbi 2006). These small plots, and large ones, are cultivated by ox and scratch plow. The plows used 
are a simple, non-bladed design with a heavy metal point attached to a long pole. With these plows the land must be plowed two to four times in perpendicular directions, demanding much of the farmers' time and labor.

\section{Water Resources}

The highlands of Ethiopia are the rainmakers for the Horn of Africa. Moist air coming from the southeast, off of the Indian Ocean, is lifted by the highland plateaus and falls as rain primarily on slopes with a southern aspect at altitudes above 1500 masl. (Table 2.1) (McClanahan and Young 1996). There are twelve major river basins that contain eleven fresh and nine saline lakes, four crater lakes, twelve major swamps and wetlands, and many small swamps, wetlands and kettle lakes (Awulachew et al. 2007).

Inland water coverage is estimated at 12,090,00o ha (U.N. Statistical Division 2010). The combination of the extreme vertical topography and tropical monsoon weather cycles has high potential for hydroelectric power generation. In 2009 over three and a half billion Kilowatt-hours (kWh) of power was produced. This is a small fraction of the estimated potential of 650 billion kWh (U.N. Statistical Division 2010).

There are over 250,000 ha of land under irrigation. Most are public, flowing through many fields, made by hand with traditional techniques or supplemented with modern pumps provided by an NGO; several large private companies implement modern irrigation techniques (Awulachew et al. 2007). 
Most of the modernized schemes are for large-scale private agriculture and floriculture projects. Traditional methods utilize hand dug trenching to flood fields, in the lowlands, while on the lakeshores of the Central Rift Valley many farmers plant in and around flood plains to take advantage of moist soil, which is a high-risk technique. If rains are heavier than average the crops can be flooded in a matter of hours.

\section{Forests and Ecosystems}

Ethiopia's forests and woodlands are one of its most important resources. Over 1.6 billion people throughout the developing world rely on timber and non-timber forest products (NTFP) at some point along its value chain for their livelihoods (U.N. Forum on Forests 2009). People have direct and indirect, consumptive and non-consumptive uses of forest and wooded lands, which include fuel, food, building materials, tools, medicines and ecosystem services such as watershed and soil conservation (Watson et al. 2007). In rural areas wood is primarily rough cut and hewn for building homes, fences, and fuel wood. In more urban areas cement block construction has become more prevalent and wood is used for high end furniture, milled lumber, roof framing, industrial wood products and conversion to charcoal for fuel (Million and Leykun 2001).

There are many estimates of what historical forest and woodland percent coverage was, with most sources citing 35-40 percent high forest coverage one 
hundred years ago. Many sources agree that current Ethiopian forest coverage is below three percent, which conflicts with the UN's reported $11.2 \%$ of the land covered by forest (Bishaw 2001, McCann 1997, Reusing 2000). This discrepancy may be from inclusion of other savanna woodlands, e.g. acacia scrub, common in the lowlands versus area of just "high forest" (U.N. Statistical Division 2010, Million and Leykun 2001, Reusing 2000, Britenbach 1961 as cited in Bishaw 2001). Regardless of how forested area has been quantified, all are in agreement that deforestation is a serious threat. "The northern parts of the highlands are almost devoid of trees" (Ofcansky and Berry 1993). Estimates of deforestation rates are as high as 200,000 hectares per year (Bishaw 2001, McKee 2007). Most of the remaining high forest cover is in the south and southwest or on steep slopes and at higher altitudes (Million and Leykun 2001, Reusing 2000). Forests and woodlands can be broken into six descriptive categories based upon dominant species (Table 2.2). 
Table 2.2: Ecological and vegetational zonation schemes and their altitudes Ecological Zone Vegetation Altitude (m)

Semiarid Acacia woodland $1500-1750$

Dry Transitional woodland $1750-2100$

Sub-humid Podocarpus-Croton 2100-2300

Afromontane mixed forest

Humid

P. falcatus forest

2300-2700

Afromontane

Afromontane cool Sub-alpine

Montane woodland, 2700-3500

Afroalpine thickets

Erica, Helichrysum, $\quad>3500$ Lobelia spp.

Source: Adapted from Lemenih and Itanna 2004 and Frankfurt Zoological Society 2007.

The forests have been degraded over the past several millennia of increasing anthropogenic influence. Historically, the biggest human impact on the landscape was in the northern areas, the centers of the Auxumite and Gondar empires and dynasties (McCann 1997). Even the most extreme slopes and terrain have been deforested and converted over to agro-pastoral use such that the effects of soil loss and erosion are extreme (Taddese 2001, Bishaw 2001). Some groups have introduced terracing to continue practicing 
agriculture on these degraded lands. In the arid south, the people living in Konso are known for practicing terracing for agriculture and living space. Their dry-stone wall terracing is so extensive and historically intact that it has earned them the distinction of inclusion into United Nations Educational, Scientific and Cultural Organization's (UNESCO) World Heritage List in 2011.

NTFPs are important to the livelihoods of people all across the developing world and can play a positive role in conservation goals in varied forest and ecosystem types (Arnold and Ruiz Perez 2001, World Bank 2003). Some of the most common NTFPs in Ethiopia are medicinal herbs, honey, gums and resins, bamboo and coffee (Frankfurt Zoological Society 2007, FAO 2010, Kassa et al. 2011). These products are sold on local, national, and export markets. Coffee is indigenous to Ethiopia and is found in natural forest stands and plantations and plays an important role as the most valuable export (Petit 2007). Arnold and Ruiz Perez (2001) also found that it was the poorest populations that were more dependent upon NTFPs for their incomes. Currently there are projects in Ethiopia that are working to understand the weaknesses of NTFP value chains and what improvements could be made in the value chain to help economic and development goals (Kassa et al. 2011). Product value chain analysis is a thorough examination of a product's market presence from raw material or resource though the inputs of labor, refinement, logistics, marketing and eventual sale to the consumer.

The biggest driver of forest and land degradation is the increase in 
population (Reusing 2000, Bishaw 2001, Kloos and Adugna 1989). Ethiopia's growth rate of $2.9 \%$, an average of 5.39 children born per woman, has resulted in a population of just over 91 million in 2012 (C.I.A. 2013). With each new generation landholdings are subdivided into increasingly smaller plots. The result is forest and woodland clearing and migration onto marginal and degraded lands for new agro-pastoral activities (Bishaw 2001, Taddesse 2001).

Much of Ethiopia's timber products come from forest plantations (Figure 2.3). It was estimated that in 2005 forest plantation containing Eucalyptus, Pinus, Cupressus covered 509,422 hectares (FAO 2010). The rate of deforestation of native forests is still on the rise despite plantations. Plantation forests may provide timber products but are not ideal to improve or sustain Ethiopia's biodiversity and endemic species. The Bale Mountains National Park is one place where there are conservation efforts to combat the loss of native forests. 


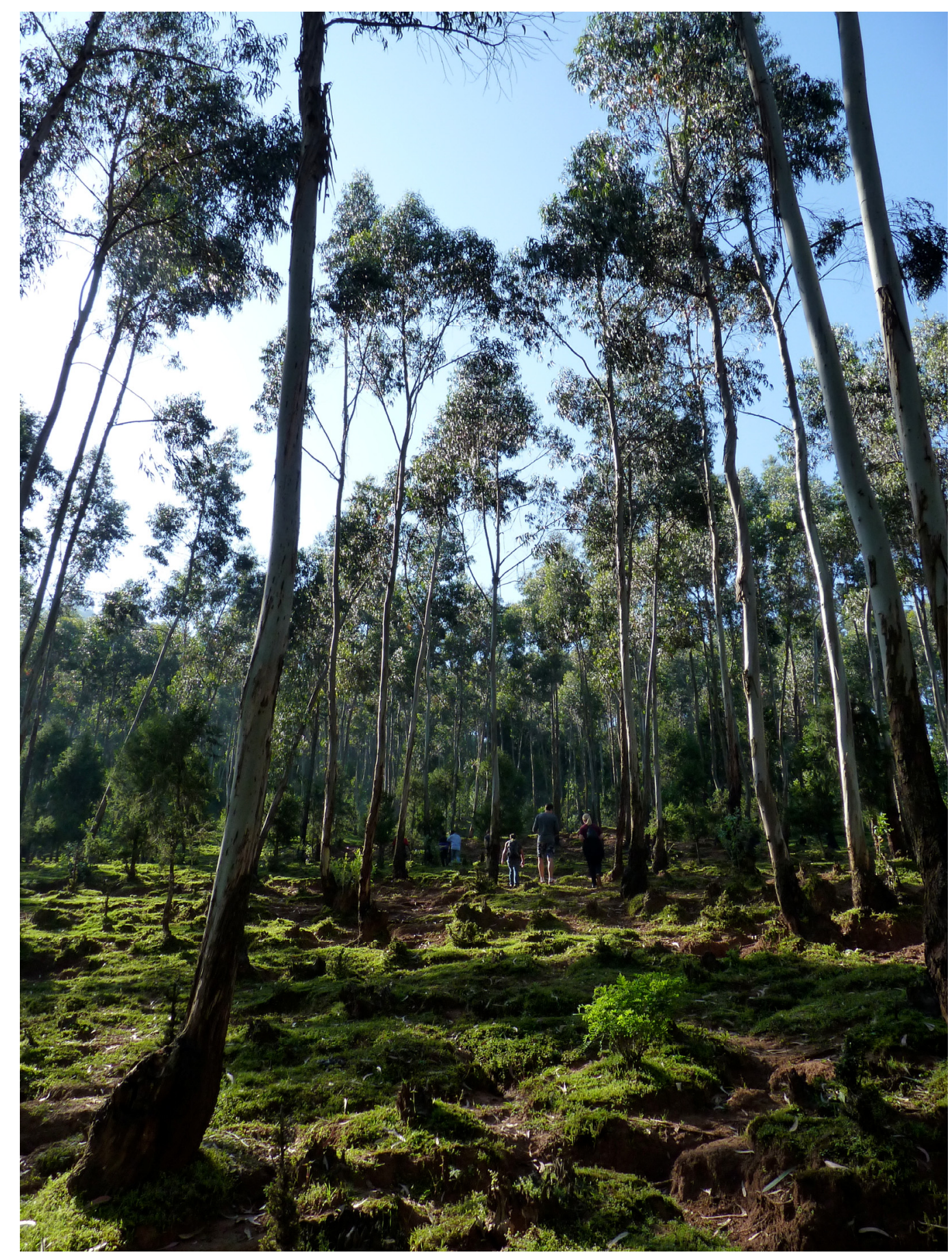

Figure 2.3: Eucalyptus plantation on a degraded hillside. (Photo by Brian Barbre) 


\section{Chapter 3: Study Site}

\section{Introduction}

This study was conducted in the town of Dinsho located in the southern highlands of the Bale Mountains, Bale Zone, within the state of Oromia (Figure 3.1). Dinsho is a small town of roughly four thousand inhabitants. It is located $400 \mathrm{~km}$ to the southeast of the capital Addis Ababa at an altitude of $2800-3100$ masl. The average temperature range is $6-15^{\circ} \mathrm{C}$ (World Weather Online 2013). Dinsho's political area or woreda contains several smaller kebeles, political zones.

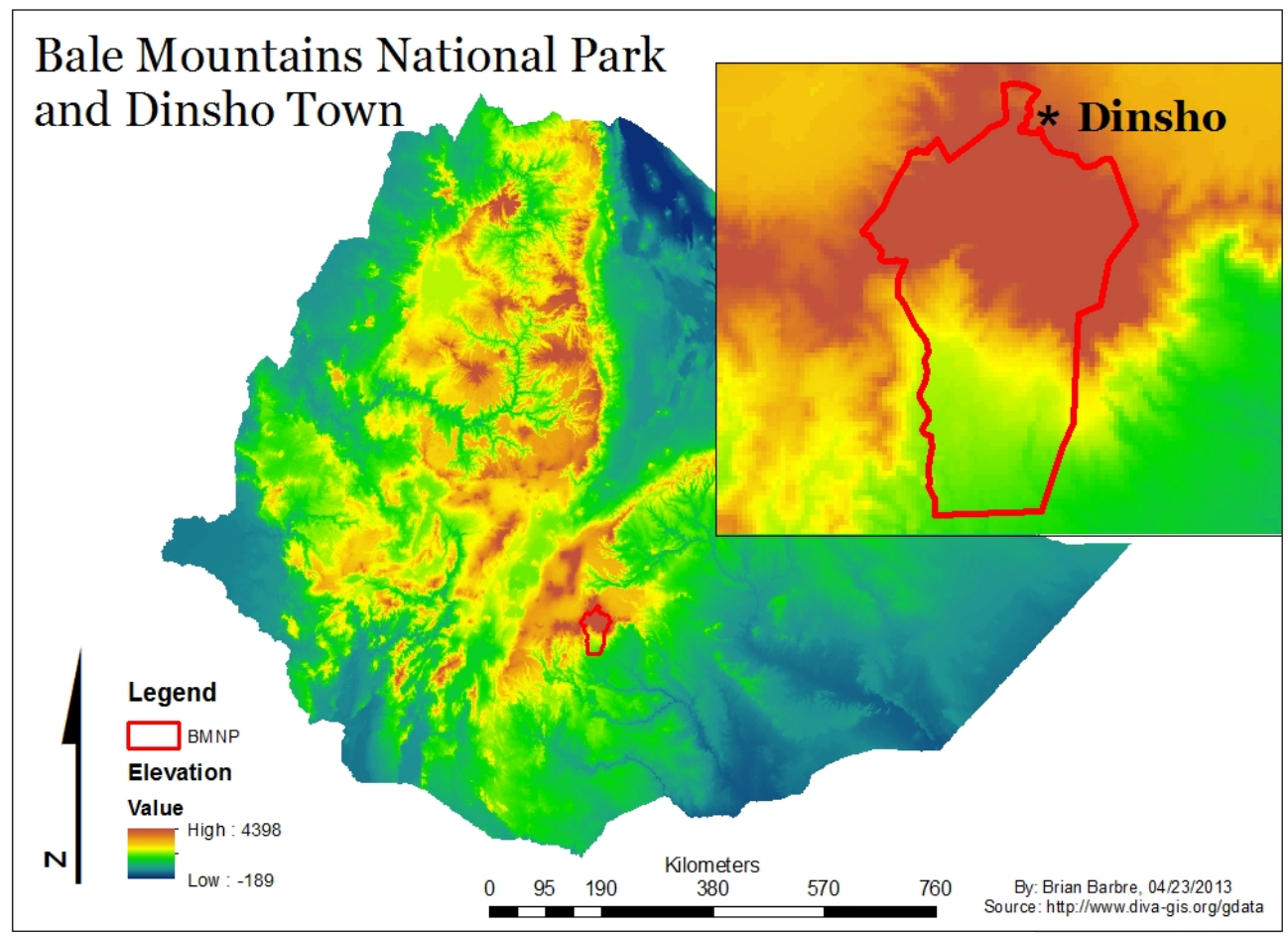

Figure 3.1: Location of Bale Mountains National Park and Dinsho town. 
Permanent settlement was sparse until the fall of the Ethiopian military regime, the Derg, in 1991. Since 1991 settlement has rapidly increased, influenced by government relocations (Ofcansky and Berry 2004), bringing with it more intensive agricultural practices from the north. This area was originally inhabited by seasonal pastoralists who came from the lowlands during the dry season to graze in the highland forest, grass and shrub lands. Expansion of large scale lowland agriculture forced permanent resettlement of lowland pastoralists to the Bale highlands (Stephens et al. 2001). Rain patterns are similar to the rest of the country but with intermittent rains blurring the transitions between rainy and dry seasons, including periodic rains during the four months of the dry season. The headquarters of the Bale Mountains National Park is located in Dinsho and is a center for conservation.

\section{Geophysical Characteristics}

The Bale Mountains were formed by Miocene and Oligocene volcanic eruptions and have gone through several glacial periods. Cored pollen samples indicate the most recent montane glaciations ended roughly 2500 years before present (Mohammed and Bonnefille 1998, Mohr 1963). Recent glacial recession has resulted in shallow soils, rock outcrops, and swamps, which limit agriculture but provide grazing lands. There are areas where soil saturation is such that even eucalyptus cannot grow.

The Bale Mountains reach an altitude of 4377 masl. at the top of Tullu 
Dimtuu (Red Mountain), the second highest peak in the country rising from the Sanetti plateau. The Sanetti is the largest contiguous Afroalpine zone on the continent and has an average altitude of 4000 masl. These altitudes generate cold and moist air masses by lifting warm wet air currents from the Indian Ocean (Camberlin and Philippon 2002). The coldest time of the year is during the dry season, November to February, when below freezing temperatures and frost are common. During the rainy season, the cold temperatures generate large damaging hailstorms and, in combination with frost, are potential threats to crops. 


\section{Biodiversity and Bale Mountains National Park}

Ethiopia's geophysical characteristics provide diverse habitats that produced high levels of biodiversity and endemism. The Bale Mountains are important in the global conservation context and especially within the Ethiopian context. They are part of Conservation International's top 34 biodiversity hot spots.

"It is estimated that if we were to lose the Bale Mountains more endemic mammals would go extinct than any similar sized area on our planet."

"The Bale Mountains National Park is the most important conservation area in Ethiopia (FDRE, 2005). It is the world's largest Afroalpine area and encompasses the second largest moist tropical forest in Ethiopia. The Bale Mountains are a centre of endemism, and are the most important area for a number of threatened Ethiopian endemics in all taxa."

(Frankfurt Zoological Society, 2007)

The most notable flagship and umbrella species are the mountain nyala (Tragelaphus buxtoni) and the Ethiopian wolf (Canis simensis) (Figure 3.2). The park is home to the largest populations of both species. Other rare and endangered animals include lions (Panthera leo) and the African wild dog (Lycaon pictus). BMNP also contains the entire global populations of several species including the Bale monkey (Cercopithecus djamdjamensis), Bale shrew (Crocidura baileyi), and the giant molerat (Tachyoryctes macrocephalus). Endemic and endangered lists contain many genera of flora 
and fauna and it is agreed that new and endemic species remain undiscovered. Bale and surrounding forests have been designated as one of Ethiopia's National Forest Priority Areas. Park staff and the Frankfurt Zoological Society are working towards obtaining listing by UNESCO as a Biosphere Reserve and World Heritage Site (Frankfurt Zoological Society 2007).
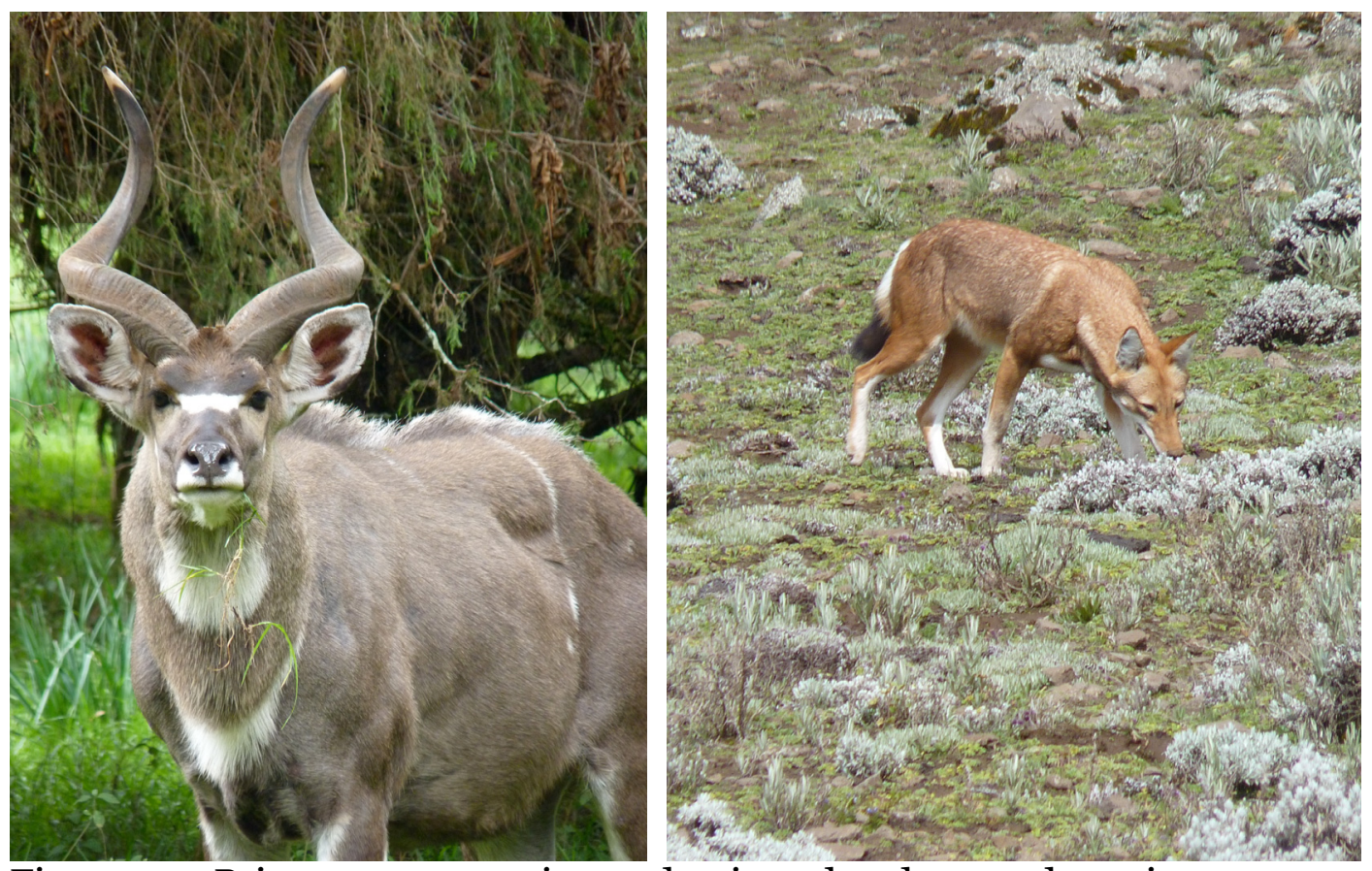

Figure 3.2: Primary conservation endemic and endangered species; Left: Mountain nyala, Tragelaphus buxtoni (Photo by Brian Barbre) Right: Ethiopian wolf, Canis simensis (Photo by Brian Barbre) 


\section{Pastoral History}

The people in southeast Oromia are traditionally a pastoral people. The Oromo engage in godantu, the practice of moving livestock to higher lands for grazing during the dry season while crops are near harvest in the lower altitudes. Local farmers report that this practice has declined over the past 20 to 25 years. During this time barley cultivation became more prominent and the population increased dramatically. Both have increased competition between cultivation and grazing lands. For those who are still primarily pastoralists it is becoming more difficult to access sufficient grazing lands without pushing into someone else's grazing area or the national park. For those who still practice godantu there may be secondary homes, compounds and even families, with second and third wives. An advantage of this system is that crop residues are often left in the fields for livestock to eat upon their return after the harvest, providing labor-free fodder and manuring of fields.

Oromo pastoralists are primarily Muslim. One traditional oral history says when the Ethiopian Orthodox Church and the Muslims were proselytizing to convert those who practiced the traditional animist religion waqefatta, the Oromo pastoralists converted to Islam because they refused to comply with the three days per week of dairy and meat fasting required by the Orthodox Church. 


\section{Population Pressure}

Ethiopia's population has been increasing at a rapid pace, almost doubling in the past fifty years. In Bale the population increase was exacerbated after the fall of the Derg in 1991. The Derg was concerned with opposition parties and rebel groups who they believed were hiding in the national park and surrounding forest areas. Settlers were removed by force. After the fall of the Derg permanent settlement began immediately. It is estimated that in 1991 there were only a few thousand permanent households, and now the most recent estimates puts the population in the Dinsho woreda alone at over 65,000.

Southeast Oromo people, especially Bale, are predominantly Muslim and in the Dinsho woreda about 95\% of the populace is Muslim (Ofcansky and Berry 1991). Most men take up to three wives, all of whom bear children. Traditionally land is divided up between male children. For each generation land holdings are increasingly smaller, forcing people either into the park, onto marginal lands or to larger urban centers. As population pressure increases in the lowlands too, more pastoralists are moving their cattle to higher altitude pastures, intensifying the competition for land. These factors combine to create greater pressure on cultivated land and are creating sociopolitical tension, especially between pastoralists and the national park.

This tension has been increasing as the park has begun to enforce prohibitions on grazing, new agriculture, new settlement, and fuel wood 
collection. Figure 3.3 is a barley field in Gojera, land that was originally inside the park boundary, now excluded by the current boundary demarcation from agricultural expansion.

Fuelwood collection and harvest from the Park is illegal but, with weak enforcement and no legal demarcation, damage continues. Those responsible for wood collection must walk farther as the harvest cut line migrates (Figure 3.4). Alternative fuels and fuel-efficient stoves could provide a critical tool in reducing the pressure on the land from human activities. 


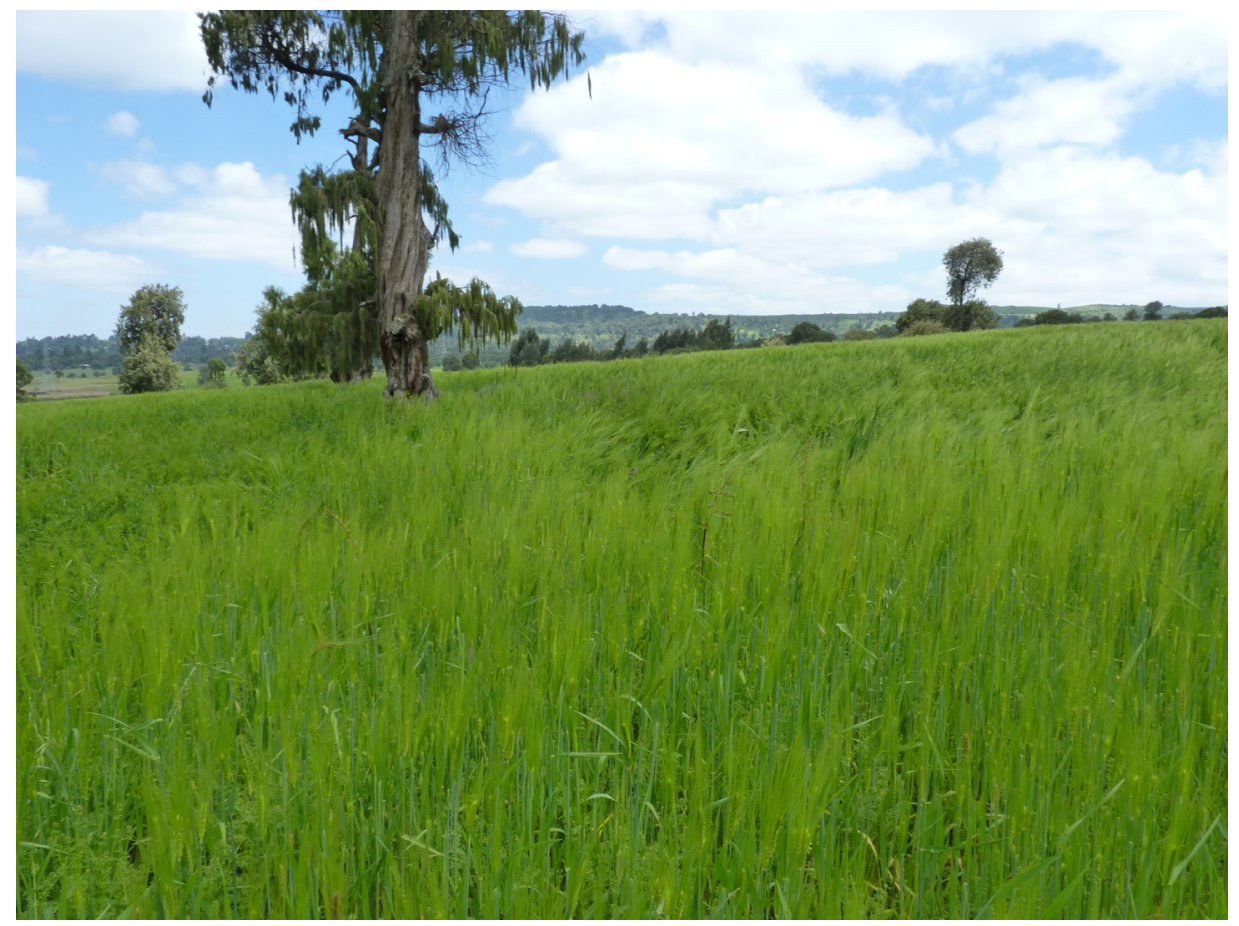

Figure 3.3: Degraded juniper forest, converted to barley. (Photo by Brain Barbre)

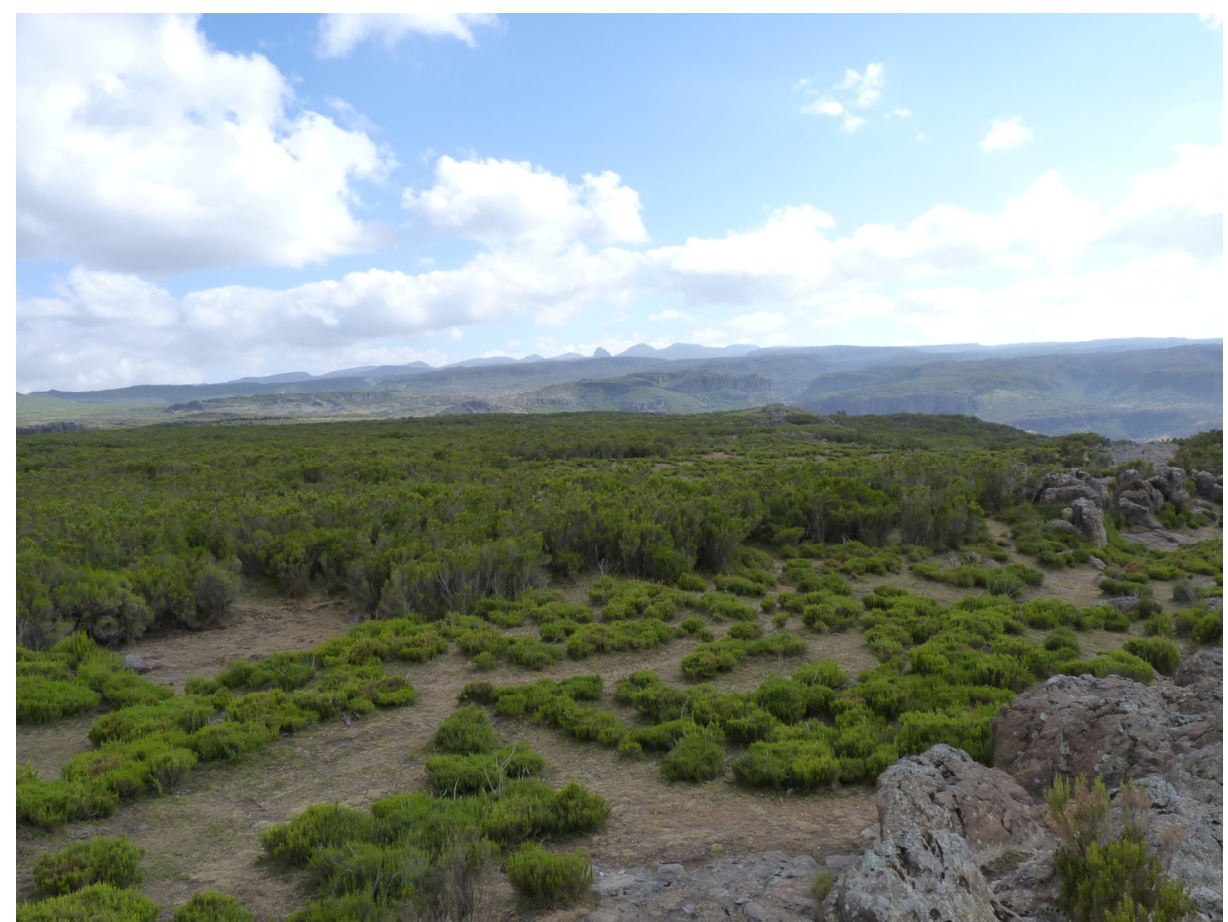

Figure 3.4: The present line of the illegal harvest of Erica species within the park. (Photo by Brian Barbre). 


\section{Chapter 4. Methods}

The objective of this project was to introduce two new technologies, biomass fuel briquettes and improved cook stoves, and observe their acceptance and the relationship between the two technologies. There were three methods of data collection. Methods for briquette manufacture followed methods in The Legacy Foundation Theory Manual (The Legacy Foundation 2003 a). Briquette performance was tested using a modified cold start waterboiling test (Aprovecho Research Center 2009). Briquette use data were to be collected on respondent filled data sheets. Survey data collection were approved by the Michigan Technological University's Institutional Review Board, reference number Mo912. This included a structured, open-ended survey and participant observation (Bernard 2002). Participants were chosen by a systematic random sample of Dinsho. Starting from the east side of town every fifth house was approached and asked if they would be willing to participate. If they were not willing the following house was asked (Bernard 2002).

Optimal briquette recipe tests were a modified water boiling test. It was modified from the Aprovecho Research Center's Water Boiling Test (Aprovecho Research Center 2009). The original water boiling test protocol is designed to recreate cooking conditions to test stove performance and efficiency. I used a similar experimental design but changed the data collection variables to focus on fuel performance. I only utilized cold start boil 
tests for each experiment.

Data collection was to occur in two (2) three-day periods. For the first three-day period each respondent was given 32 briquettes, twelve per day, to use with any cooking technique they wanted. They were to record briquette use and cooking method per meal on the data sheet provided. After using briquettes for three days I would return to collect the briquette use data sheet and administer a face-to-face structured, open-ended survey. Survey respondents rated performance characteristics by numerical scales and openended questions. During the second three-day period the same respondents were given 32 more briquettes and an improved stove and a briquette use data sheet that included the improved stove. Again, after three days I would return for data sheet collection and to administer the second survey.

As a community member I collected participant observation data (Bernard 2002). Once I introduced the new technologies into the community, briquettes and stoves became a common topic of conversation. I also took notes on each step during project development and implementation.

To calculate briquette pricing, measures of mean and median were used. Mean and median were calculated for the answers to, "How much would you pay for a briquette?" and "How much money did you save? (fuelwood saved)" These two answers were compared to determine an appropriate price for briquettes. 


\section{Chapter 5. Project Implementation}

\section{Introduction}

In this chapter I will discuss the steps involved in project implementation. I will discuss briquettes and stoves independently (Figure 5.1). Figure 5.2 shows the steps I planned to follow. In each section I will detail the problems I encountered and, as a result, what actually happened. Figure $5 \cdot 3$ shows the amended flow chart.

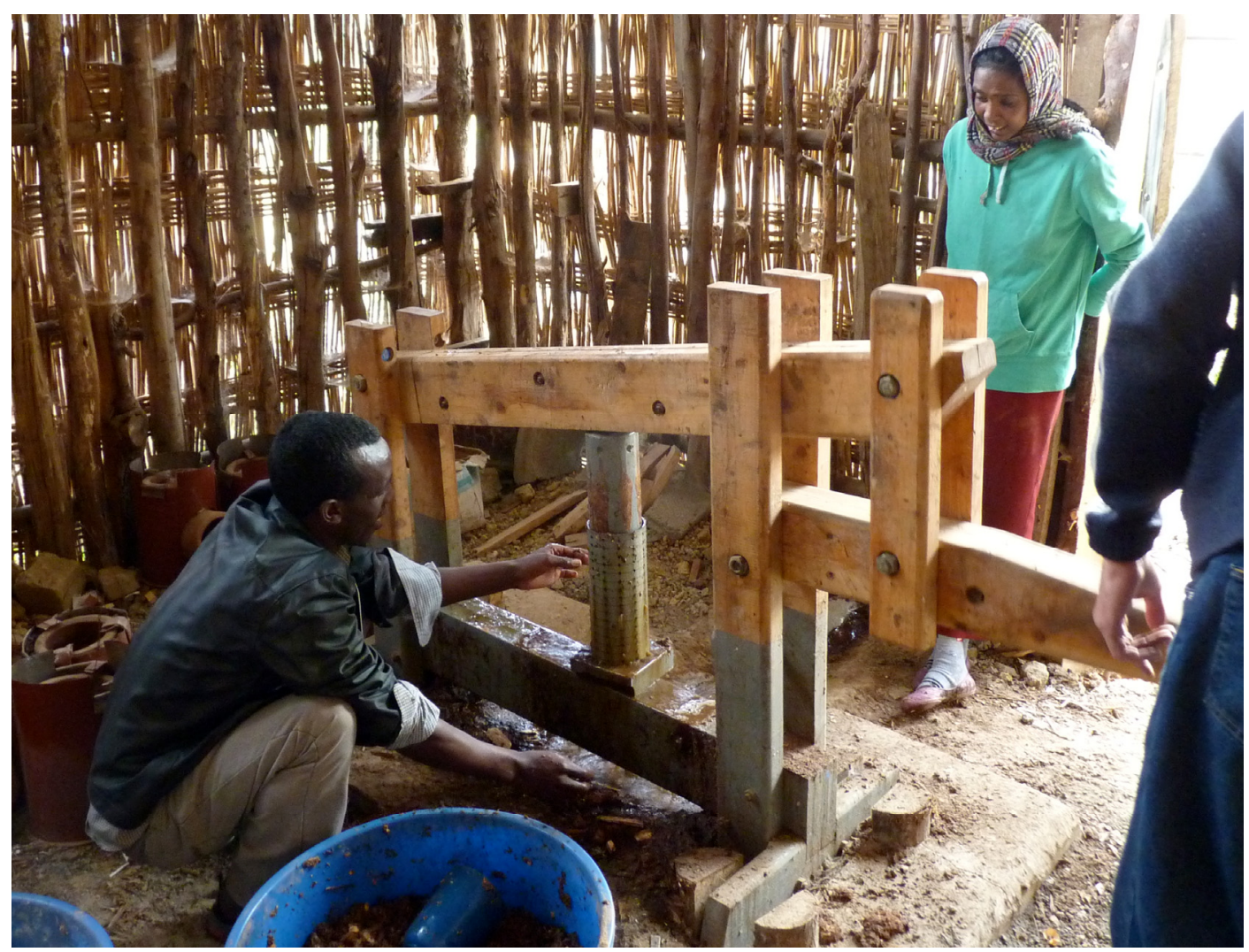

Figure 5.1: Briquette press in use during a training session. (Photo by Brian Barbre) 


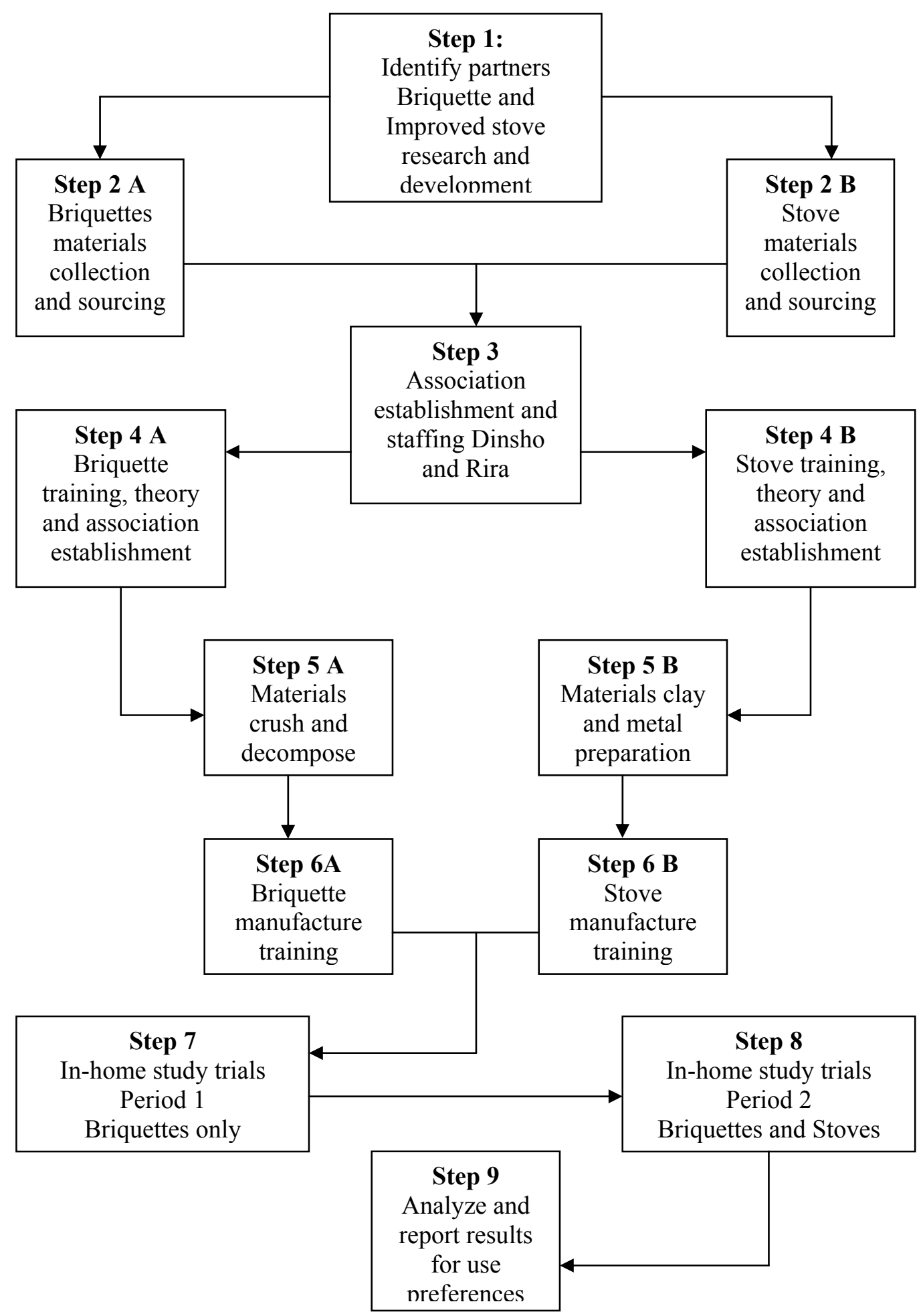

Figure 5.2: Flowchart of desired project framework. 


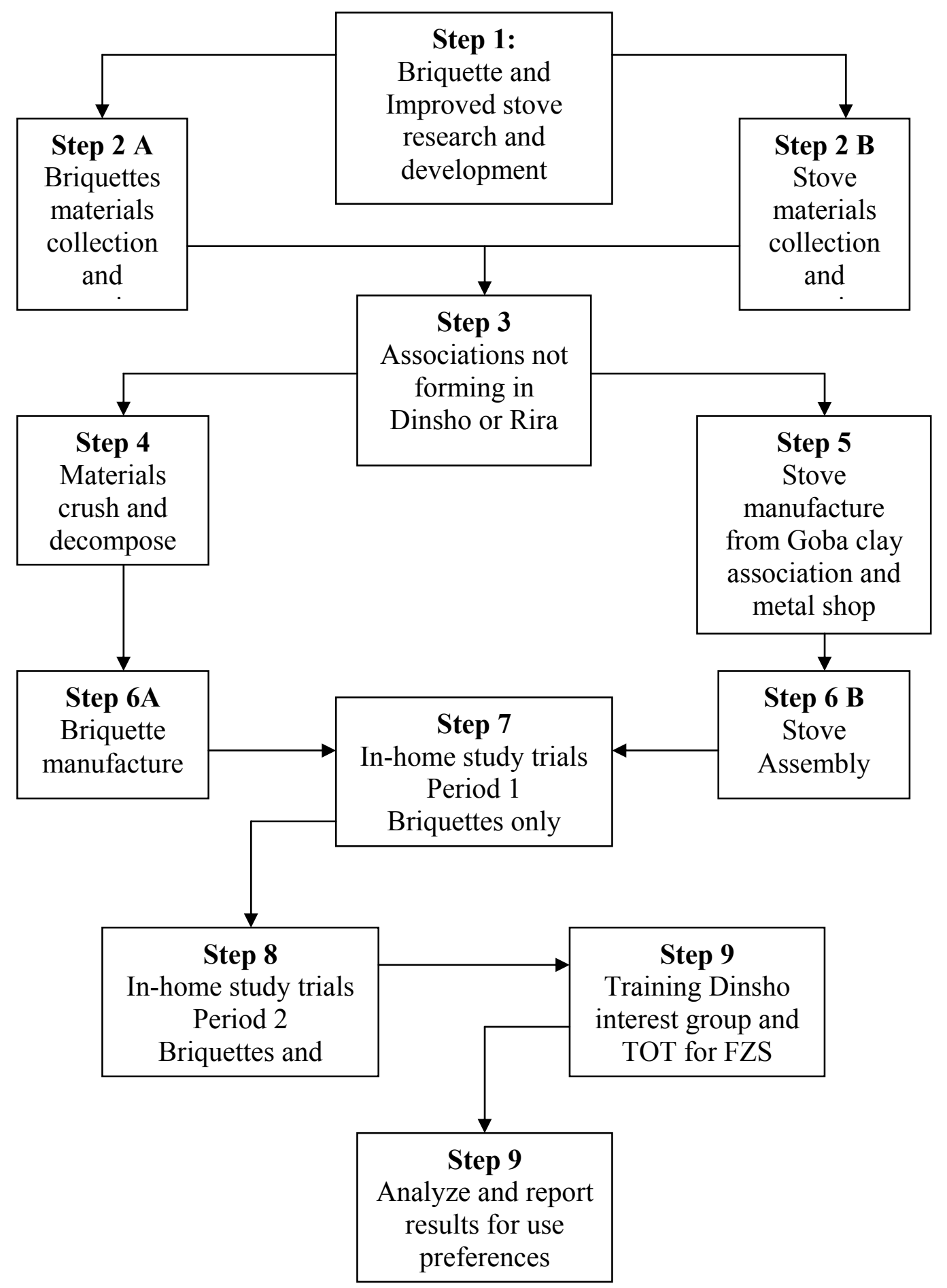

Figure 5.3: Amended flow chart showing actual steps taken. (TOT is training of trainers) 


\section{Step 1: Fuel Briquette and Stove Research and Development}

Each briquette program is different based upon the types and availability of local biomass materials. Agricultural residues are the most common materials used. The agro-climactic conditions and traditional agricultural practices of the Dinsho woreda limit crop production primarily to barley, from which there is no agricultural waste. Barley husks, straw, and residues left on the fields are used as cattle fodder during the dry season.

I met with Kebede Tilaye, the FZS construction manager who was in charge of the previous briquette experiments, to discuss what materials had been used in the past. FZS had used koso (Hagenia abyssinica) leaves, sawdust and paper. I wanted to understand what had caused the poor briquette performance, which included unpleasant odor, excessive smoke and low heat output. I broke apart several of the old briquettes to determine their ingredient ratios and processing methods. The briquettes' poor performance was from irregular materials processing and the ratio of koso was too high (The Legacy Foundation 2003 a).

Women had said they did not like to use koso leaves because they are difficult to light, produce too much smoke and have a bad odor. Because of their availability I decided to continue to use koso leaves, but in lower quantities. I mixed them with eucalyptus leaves in a $50: 50$ blend. Eucalyptus leaves are commonly used as a fire starter and produce a pleasant odor that 
would help mitigate the unwelcome odor of the koso.

To avoid complex weights and measurements and provide a measuring unit that would be familiar to host country nationals I used commonly available cement and quintal sacs for materials collection and handheld pitchers for mixing. Ten empty $80 \mathrm{~kg}$ cement bags were filled with $k o s o$ and eucalyptus leaves by FZS employees and delivered to the CASTLE. Leaves were spread out, dried and then crushed with mortar and pestle.

To partially decompose the crushed leaf matter it was placed into a pit that was lined and covered with black plastic tarp and moistened. This pit had been dug during FZS's experimentation the previous year. The pit was to help insulate and warm the pile to speed up decomposition in the cold climate. FZS and EWCP office waste and old newsprint were the paper source. Kebede supplied two quintal sacks of coffee husks and sawdust. Husks came from the coffee processing plant in the town of Delo Mena to the south of the Park and the sawdust was from a local wood working shops in Dinsho and Goba towns.

The first trials were experimental with differing ratios of ingredients. The binding materials were paper and leaf mixture. Sawdust and coffee husks were fillers. The average ratio of binder to filler should be $50: 50$. That is ratio I began experimenting with. Table 5.1 has the complete list of ingredient ratios for all eight trials. Briquettes were judged qualitatively on the criteria of: how well each slurry mixture withstood a squeeze and shake test, how evenly the slurry poured into the perforated cylinder (uneven pours would 


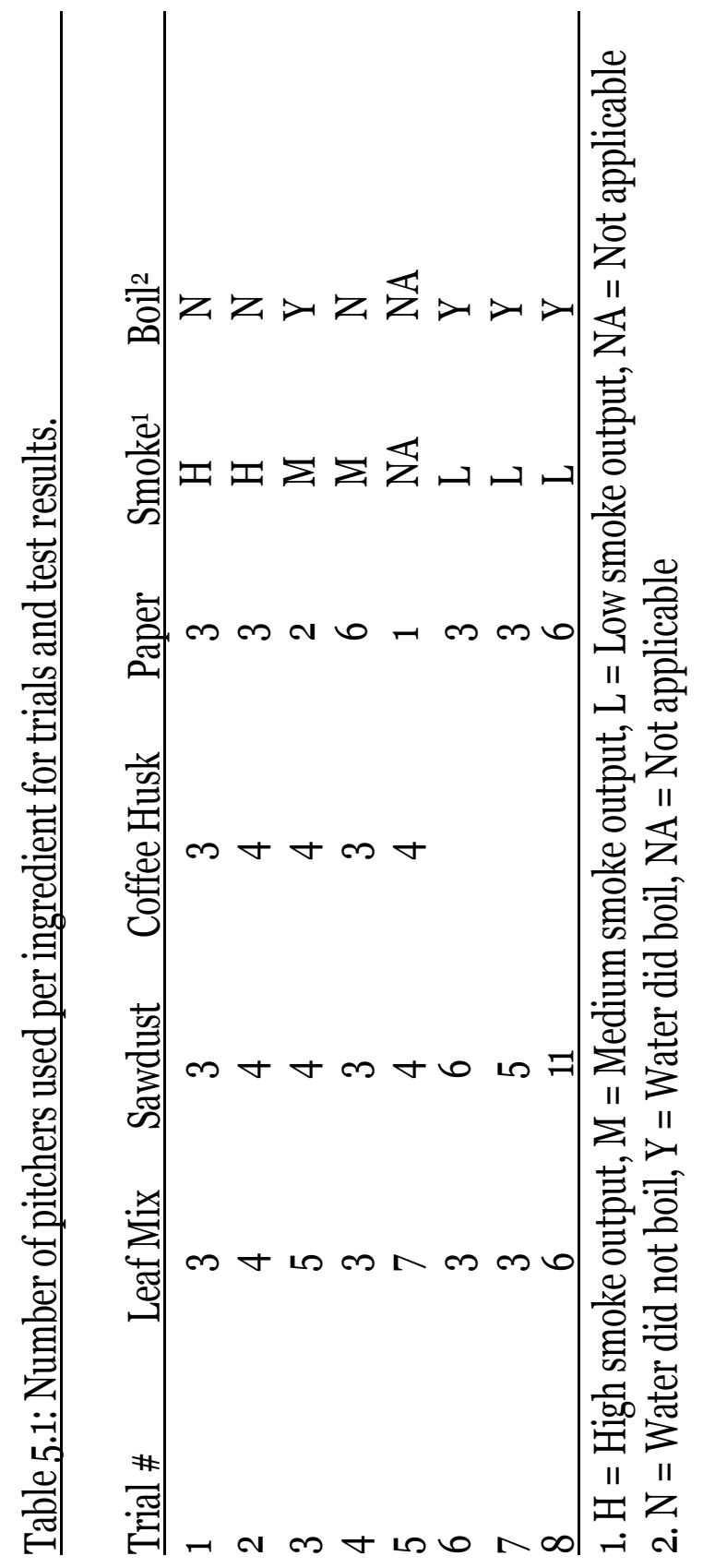


result in uneven briquettes in shape and density), how dense the briquettes were after drying, and mixture homogeneity. For the squeeze test the briquette maker takes a handful of the material and squeezes firmly to remove as much water as possible. If the handful does not fall apart and retains its shape it is then held between the thumb and index fingers and shaken like a saltshaker. If it still holds together the material is ready to be pressed (The Legacy Foundation 2003 b) (Figure 5.4). Burn tests were conducted for qualitative smoke output observations and cold start water-boiling tests (Table 5.1, Figure 5.5).

Briquettes containing coffee husks burned for an average of 40 minutes, had no open flames, and thick smoke (Figure 5.5). The only briquette containing coffee husks that was able to bring water to a boil was the $5: 4: 4$ : 2 mix. Coffee husks created poor homogeneity and non-uniform densities that caused flaking and breaking while being dried and transported. 


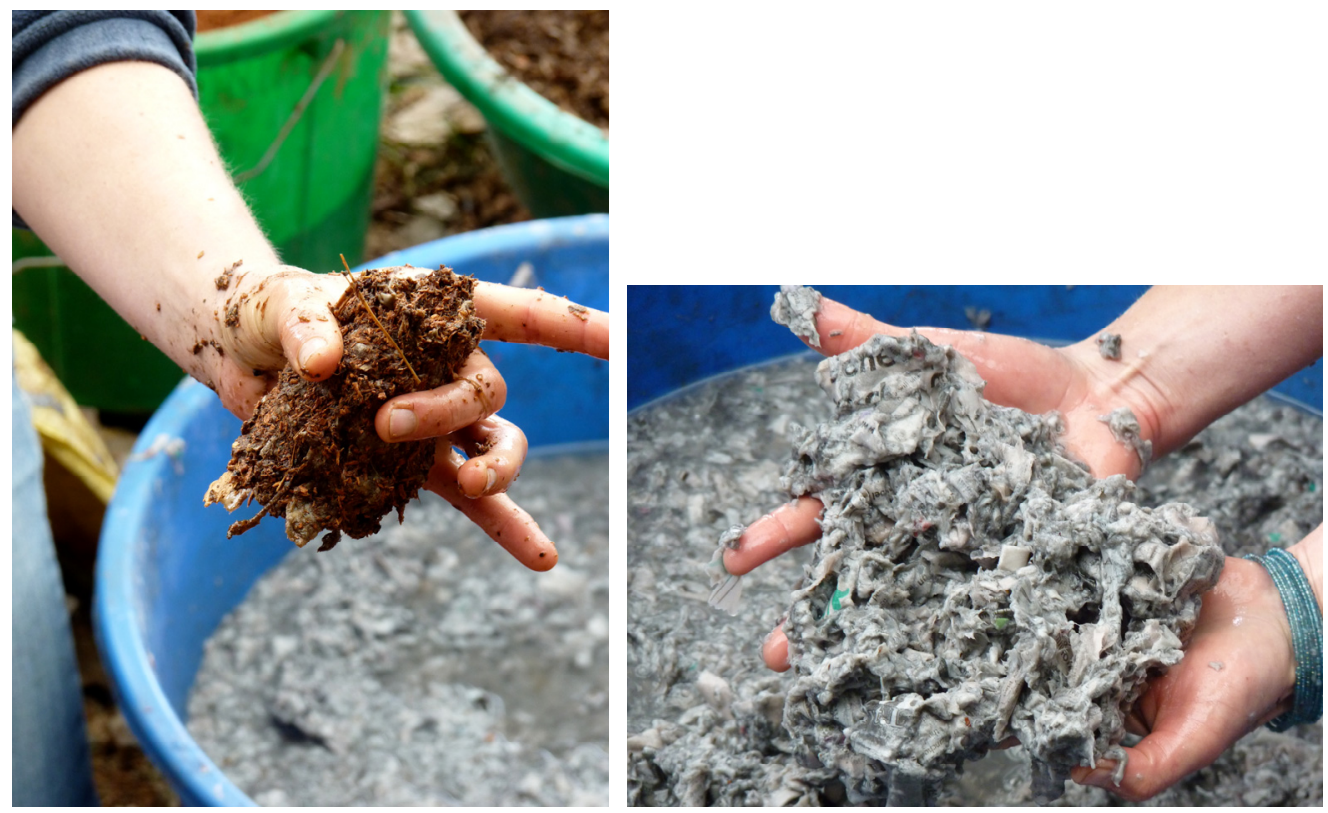

Figure 5.4: Left; Materials that have passed the squeeze and saltshaker test. Right; Paper that has been soaked in water and pulped, ready for mixing. (Photos by Brian Barbre)
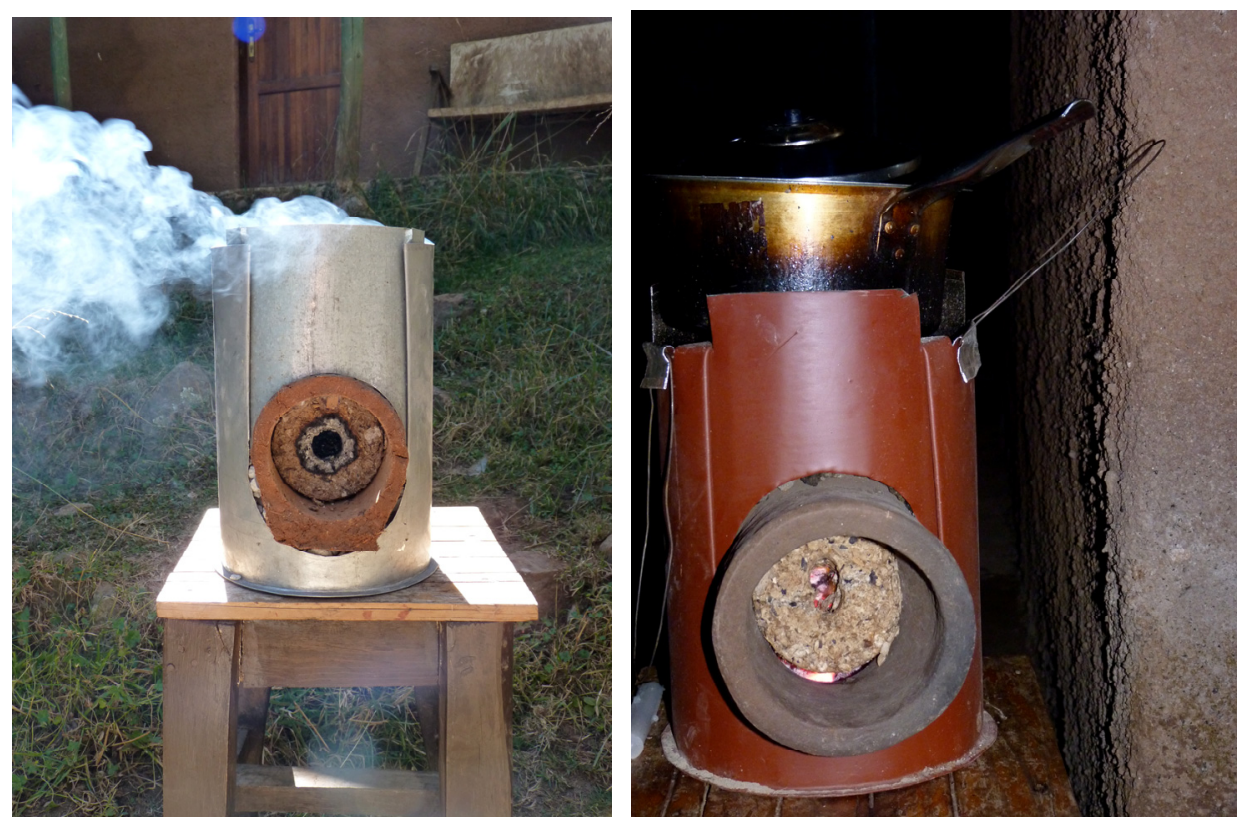

Figure 5.5: Left, preliminary burn test. Right, water-boiling test. (Photos by Brian Barbre) 
The addition of too much of pre-processed commercial materials, including coffee husks, could cause this spongy quality and make briquettes fall apart (The Legacy Foundation 2003 a).

The Oromia Forest and Wildlife Enterprise (OFWE) and the German Society for International Cooperation (GIZ) had conducted independent research into coffee husks utilization. Both groups decided that coffee husks need carbonization prior to being pressed into briquettes. Carbonization of coffee husks would have brought another level of labor and expense to the project so their use was discontinued. The volume of sawdust was increased to equal the volume of husks removed. The manufacture and performance of these briquettes improved in the following characteristics:

- Slurry poured more evenly into the cylinder

- Greater homogeneity

- More dense

- Chipped and broke less during drying and handling

Previous water boiling tests had failed, but both non-husk recipes had average water boiling times of 7 minutes. They produced open flames and had an average complete combustion time of 20 minutes, almost half of the previous tests. The final recipe used for the trial was a combination of the two nonhusk mixtures then doubled in size. One double recipe filled a single mixing pail, and could still be moved around the workspace by one person.

The second half of this study was based on improved stoves and what 
their influence on briquette use might be. With a basic understanding of rocket stoves and appropriate technology principles I hoped to design a stove that would be fuel efficient regardless of fuel source, accommodate briquette use, and utilize local materials and non-specialized construction methods. I researched current and past projects to see if there were stove designs that would be appropriate for mixed fuelwood and briquette use. To allow for both fuels there would need to be a fuelwood support shelf that could be removed when using briquettes.

I visited shops and markets in Dinsho and Robe, the Bale zonal capital, to understand common construction materials, construction techniques and price ranges for stoves. Sheet metal was the most common material used, but varied widely in quality from thin $1 \mathrm{~mm}$ tin sheets to $3 \mathrm{~mm}$ galvanized steel. Some stoves had ceramic linings to extend their lives. Stoves ranged in price from 40 birr to 150 birr ( $\$ 1$ USD $=18.42$ ETB (XE Currency Converter 2013)). All stoves had a two-chamber design. Top chambers are open and support pots above charcoal. The lower chamber serves two purposes, to catch ash that falls through the perforated bottom of the upper chamber and supply air to the fire through one or two side openings (Figure 5.6). 


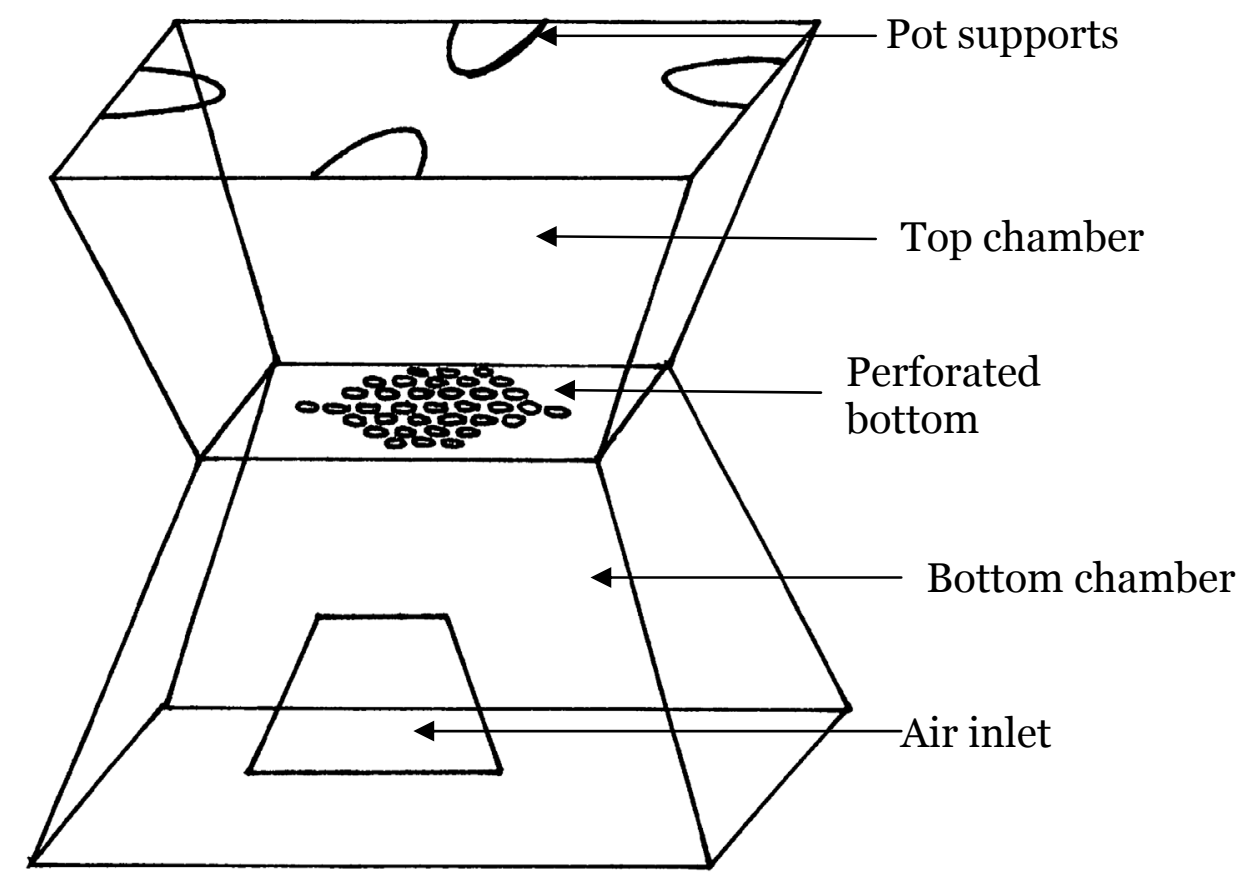

Figure 5.6: Traditional two-chambered charcoal stove. (Figure by Brian Barbre)

My design was influenced by Larry Winiarski at the Aprovecho Research Center and Rok Oblak's "holey rocket stove”, and GIZ prototypes (Still et al. 2000, Holey Rocket Stove undated). These designs are all single chamber rocket stoves. The chamber has a $90^{\circ}$ elbow that differentiates the fuel, combustion and chimney areas. Rocket stoves are more efficient and burn cleaner than three stone fires and traditional wood and charcoal stoves (MacCarty et al. 2008). They use smaller quantities of fuel and concentrate hot gasses through the chimney. 
The "holey rocket stove" is designed to burn fuel briquettes only and is made entirely out of clay. Over time a metal combustion chamber will burn out. Including ceramic combustion chambers will extend stove life. Clay soils are abundant in Bale. There are large clay deposits in Goba town that support a clay workers association and a clay deposit within the CASTLE compound. Clay was chosen because of its availability, cultural familiarity, and adaptability for stove use.

GIZ provided me with plans and prototypes of two different ceramic rocket stoves as the basis for my project. They were one and two-piece ceramic designs. I decided to use a two piece ceramic interior with a metal exterior design (Figure 5.7). I designed metal molds to produce them to specific standards. Each mold presses one vertical half of a ceramic stove liner. I was put in touch with a metal worker in Addis Ababa to discuss manufacture of the ceramic molds. The complete manufacture period for the two molds took just over three months and three trips to Addis Ababa to find appropriate materials and adjust my design (Figure 5.8).

I met with a local ceramic worker from Goba to see if she could manufacture one- and two-piece ceramic stove liners and to determine how difficult and expensive manual production would be. She produced twentytwo liners of both one-and two-piece types (Figure 5.9). The problem with her manual production was the slight variation from stove to stove. 

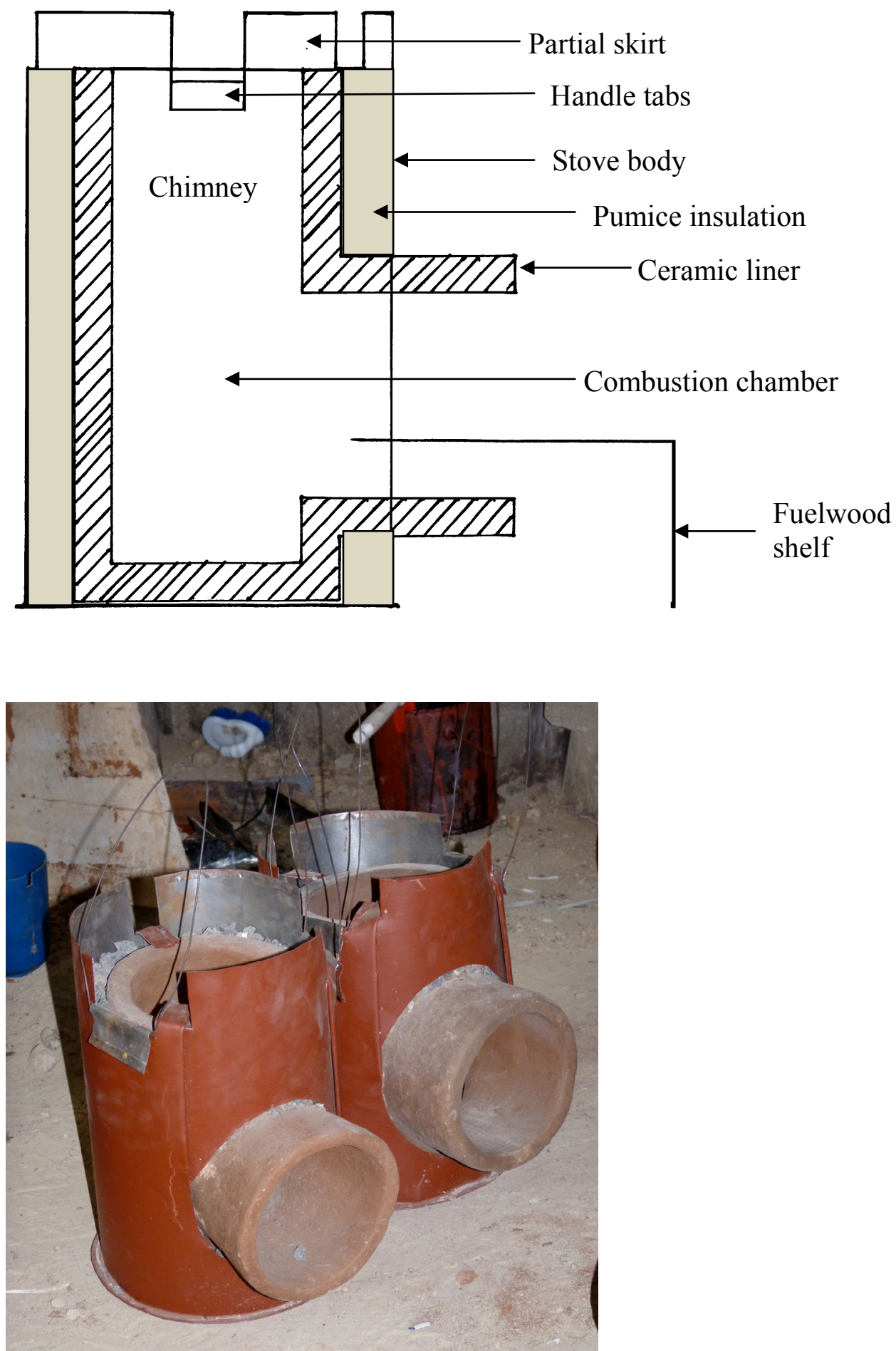

Figure 5.7: Top, stove cross section. Bottom shows two assembled stoves. (Photo and Figure by Brian Barbre) 


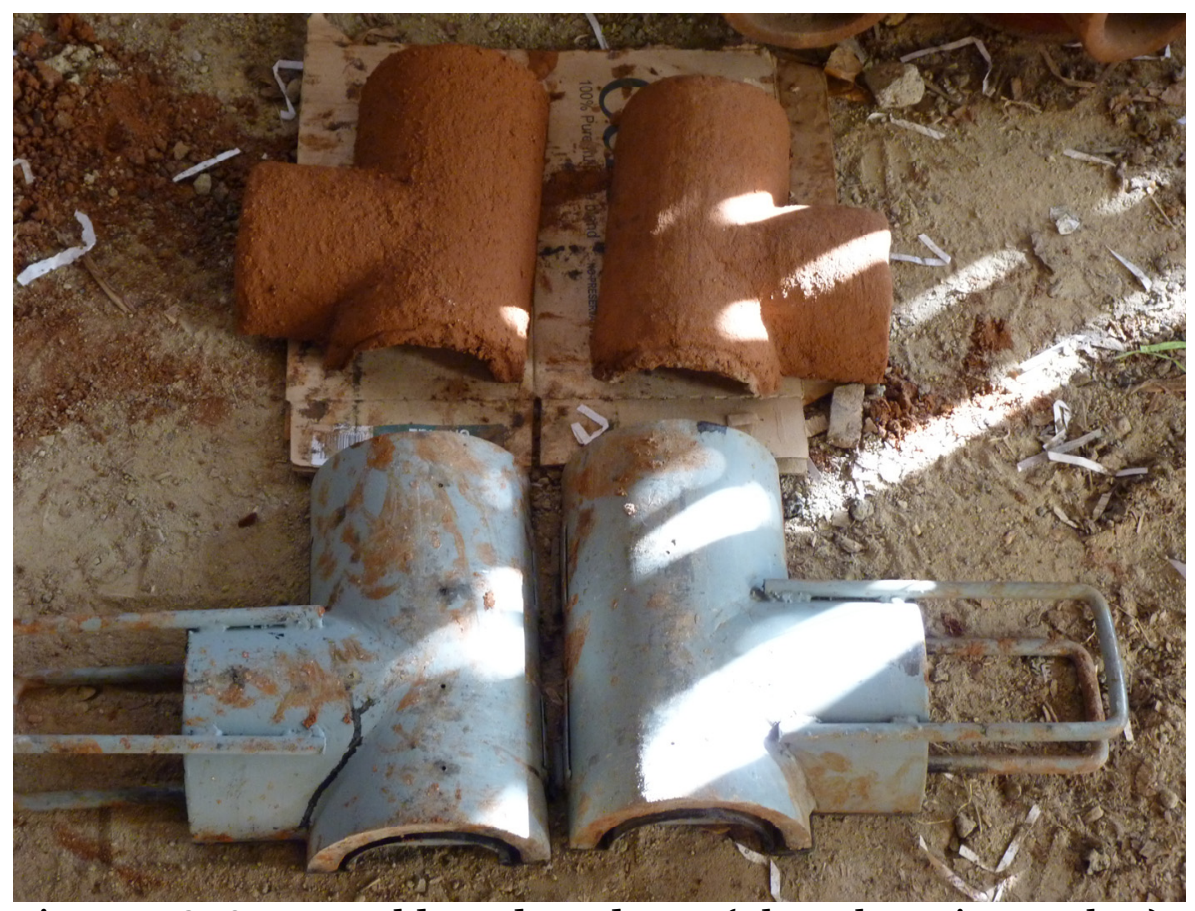

Figure 5.8: Stove molds and products. (Photo by Brian Barbre)

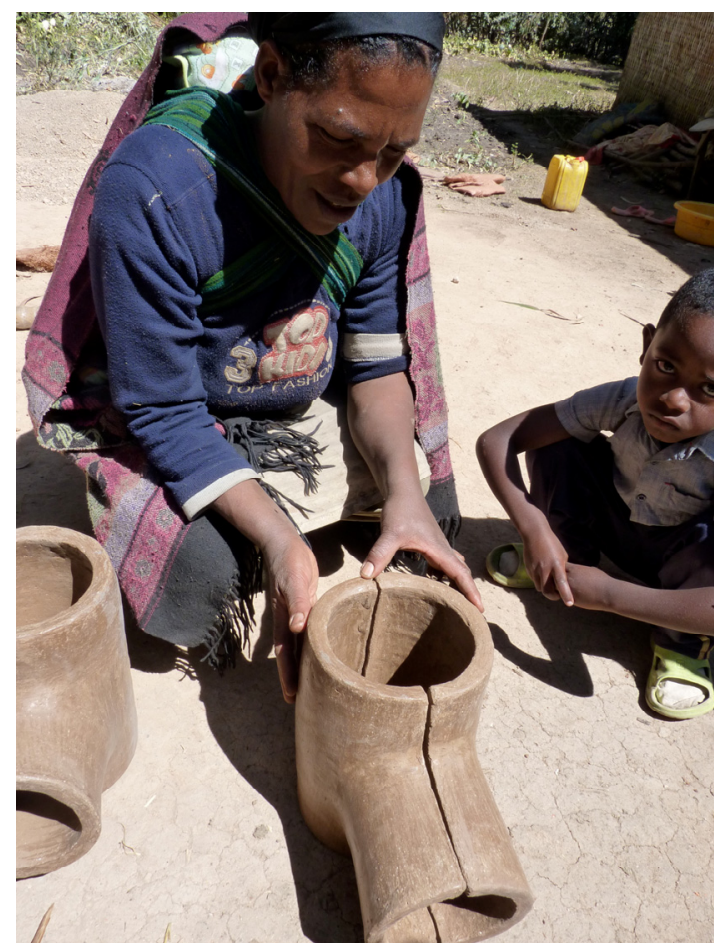

Figure 5.9: Clay worker from Goba with one and two-piece stove liners. (Photo by Brian Barbre) 
For stove body construction I took the original GIZ prototype with descriptive measurements to a metalworker in Goba who made twenty copies. They were expensive, 300 birr each, because of the heavy gauge galvanized steel he used and the difficulty of manufacture. They were assembled with the ceramic liners made in Goba. The twenty assembled stoves were used for the community trials (Step 5B Amended Flow-Chart).

While experimenting with the operation of the ceramic molds I discovered three problems with the ceramic material: sticking to the inside of the molds, deforming as it dried, and developing cracks while drying. I tried coating the inside of the molds with sand, sawdust, used motor oil and plastic sheeting. Sand and sawdust did not coat the inside evenly enough. Motor oil began to mix with the ceramic material and caused uneven drying and crumbling. If the clay dried too quickly it developed large cracks and on occasion fell apart completely. Leaving the plastic sheet on top of the clay after removal from the mold would allow it to dry slowly. After a day or two, with the plastic covering it, a mixture of pure clay and water was applied over the entire liner to fill any small cracks and smooth the surface.

Plastic sheet placed into the molds prior to filling with clay worked well for removing the clay after pressing, but once removed the ceramic would collapse under its own weight. To solve this I lined the inside diameter of the mold with a thin metal insert which had been hammered into the desired shape. These inserts allowed the wet ceramic material to be removed easily 
and rest on the metal insert to hold its shape while drying (Figure 5.10). Inserts were hand hammered from the thinnest, cheapest sheet metal available. Insert manufacture was kept simple and inexpensive to avoid adding another expensive and labor-intensive step.

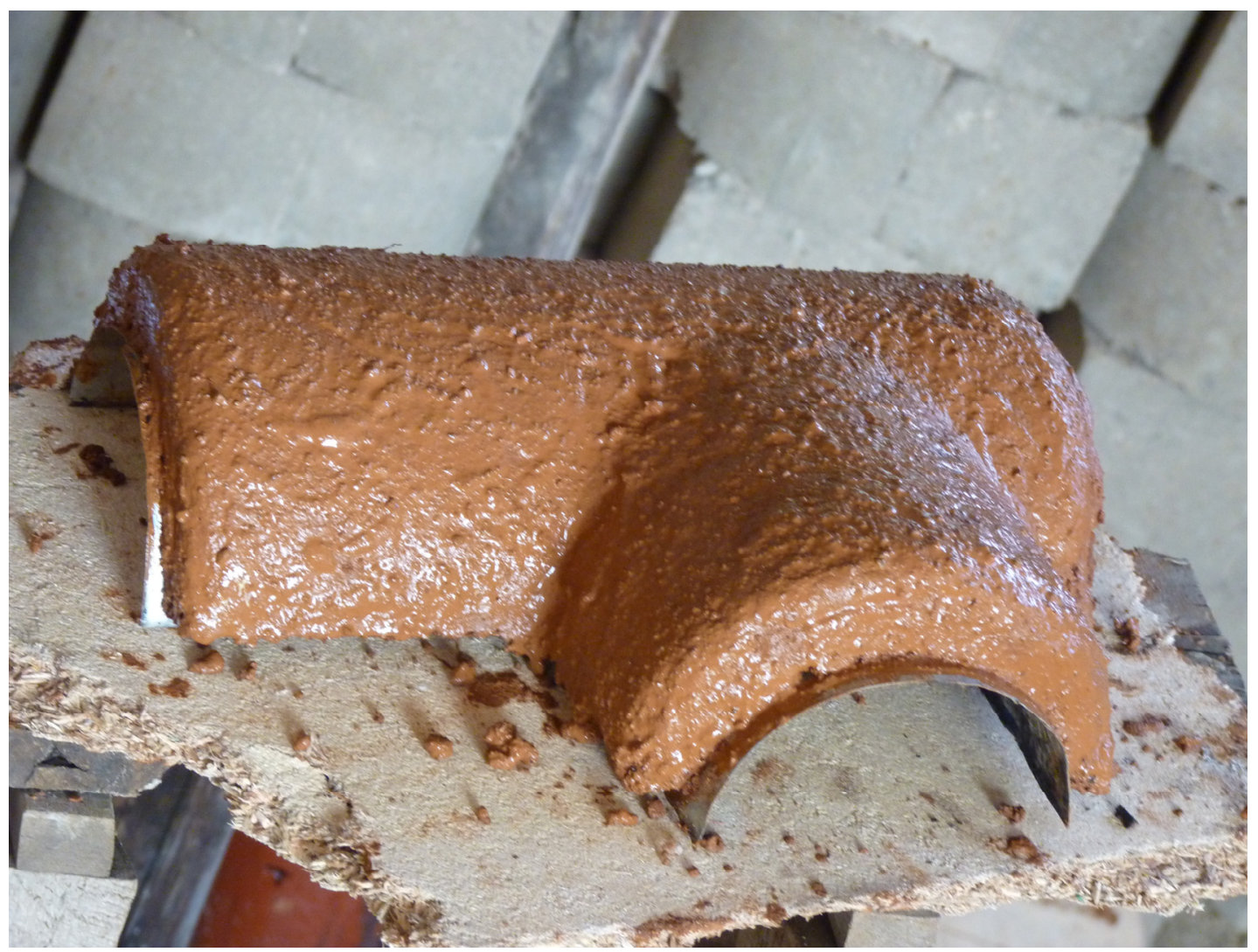

Figure 5.10: Wet ceramic from the mold resting on metal liner. (Photo by Brain Barbre) 


\section{Step 2 A: Briquette Materials Collection and Sourcing}

The next step was to create material supply lines for koso, sawdust, eucalyptus, and paper that would create a steady feedstock source for full time briquette manufacture. The large compound leaves of the koso trees produce thick leaf litter year round. One benefit is that koso leaves could be collected from the park as a NTFP. They would require regular collection by hand and would be the most labor intensive of the ingredient collections.

Sawdust was collected from carpentry shops in the town of Robe $30 \mathrm{~km}$ away and from within the park itself. Sawdust was shoveled from the carpentry shop's floor into quintal sacks at no charge. We were encouraged to take more as waste buildup takes up workspace and can be a safety hazard. Workshops agreed to regular collection. The second source of sawdust was a large koso tree that had fallen next to Park and FZS offices. It was milled on site to be used for park facilities construction and while good for this project it was a finite source.

In the town of Goba, $55 \mathrm{~km}$ to the east, there is a large government plantation forest cultivating eucalyptus and cypress. Their presence supports five zonal sawmills generating large amounts of sawdust. These sawmills were never formally contacted about supplying sawdust for this project as wood shops and the park provided an ample supply for my time there. However sawmills could be utilized in the future whenever possible as most mills and shops will allow collection for free. 
Also, from the Goba plantation forest, eucalyptus leaves are collected by the OFEW and processed for eucalyptus oil. After oil extraction leaves are discarded in large outdoor piles, which are occasionally burned. This was a great opportunity for a eucalyptus leaf supply line. I met with one of the OFWE managers at the site to inquire if they may be available for use. The initial response was positive, but I was told it would need approval from the director. The FZS Project Director emailed the OFWE director inquiring about the possibility of acquiring leaves. The director's response was negative with the explanation that someone else had claimed the leaves. After two months we were eventually given permission to collect the leaves free of charge.

NGO offices and schools create large amounts of paper waste. I contacted a PCV who worked in the school system in Robe to setup paper collection in one or more of his schools. I supplied him with quintal sacks and arranged a pick up time. The school was receptive to supplying a briquette association with paper on a regular basis. Along with waste paper were other types of trash from the floors of the school. This required more labor during processing to separate the useable paper waste from other rubbish, mostly plastics.

\section{Step 2 B: Stove Materials Collection and Sourcing}

Material acquisition for stove manufacture involved two steps, determining effective clay use methods, and finding a better option for stove 
body manufacture. Clay soil from different sources contains different percentages of clay particles. Percentage of clay particles will change how the clay soil is used. To determine percent clay I used the technique described in Build Your Own Earth Oven by Denzer and Field (2000). The clay soil at the CASTLE was roughly 50\% clay. Sand is a common amendment to ceramic products. I conducted percent shrinkage tests to determine the optimal clay to sand ratio (Denzer and Field 2000).

To locally manufacture stove bodies I met with two metal workers in Dinsho to discuss alternative stove body designs and fuelwood shelf construction. Both said they could manufacture stove bodies similar to what was commonly in use with charcoal stoves that could be modified to house the ceramic liners. This had three added benefits; local manufacture, lower cost than the GIZ design, and increasing the number of individuals in the community who would see increased income from this project.

\section{Step 3: Association and Group Establishment}

One setback I encountered was establishing the interest groups and associations. Within the Oromo state all micro enterprises and new associations have to be approved, set up, and staffed by community administration association offices. The man in charge of the Dinsho office had agreed to have new members hired for a preexisting association within one to two weeks. During the following month I and Iban, the lead FZS Community 
Liaison Officer, approached him several times about what progress had been made; there had been none. He then disappeared for a three-month period. At this point we gave up on a community association and focused efforts towards training FZS staff. In Rira there was also an FZS and Peace Corps presence. After several visits and inquiries it became clear that there was no interest within Rira to start a briquette or stove program.

\section{Step 4 A and B: Briquette and Stove Theory and Training}

Associations were never established in Dinsho or Rira so formal theory and training sessions did not take place as anticipated. Instead I made briquettes for the study.

\section{Step 5 A and B: Materials Processing and Preparation}

There was a second round of leaf collection and crushing by FZS employees (Amended Flow-Chart, Step 4A). I continued to press briquettes from the prepared materials while beginning the composting process for the new raw materials (amended Flow-Chart, Step 5A).

\section{Step 6 A and B: Briquette and Stove Manufacture Training}

Briquette and stove manufacture training could have happened simultaneously or independently depending upon when and how the 
associations were set up. Steps 5 A and B in the amended flow-chart replaced this step.

I collected stove bodies from Goba and painted them with a rust resistant paint to improve their visual appeal and increase their lifespan. After three more visits over a two-month period to the clay workers association, the ceramic liners were complete. Assembly of the stoves followed these steps (Step 5B Amended flow-chart): (Figure 5.7).

1. Place the ceramic liner into the metal body

2. Lower the metal slide to hold liner in place

3. Fill space between liner and body with insulative pumice stone

4. Make vertical cuts in the top of stove body for tabs

5. Fold three tabs down for pot supports

6. Fold down two for handle placement

7. Leave the rest of the tabs up for partial skirt

8. Cut and bend metal fuelwood shelf for wood burning

\section{Step 7: In-home Trials, Period 1}

During data collection I encountered several problems. Leaving data sheets in respondents' homes was not a sound method. Many of the data sheets were reported lost. All but one of the sheets returned were filled out 
incorrectly. Respondents would say they understood the purpose and methods of the study when, in fact, they either did not understand the methods or did not care about the results. Some first period respondents returned empty data sheets.

On several occasions I returned after the three-day period to conduct surveys and collect data sheets and the mother would send a child into the house to get the data sheet. The child would be gone for several minutes, only to return with data sheet and writing utensil in hand having freshly scribbled some marks on the page, suggesting that the information had just been manufactured. This inconsistency invalidated the data and wasted most of the briquettes. After several first period data collection disasters I used a data sheet that had been filled out correctly as an example, which helped somewhat for the second period of data collection.

\section{Step 8: In-home Trials, Period 2}

Given the shortage of briquettes and the multiple failures of first period data collections I decided to focus on Period 2 data collection to maximize information on briquettes and improved stoves being used in combination (Amended Flow-Chart, Step 7). Despite clarification efforts, second period data collection encountered similar problems to the first. I emphasized the structured, open-ended survey and relied less on briquette data sheets (Appendix 2). This provided some interesting results and insights that were 
not intended in the original study design and will be discussed in Lessons Learned (Monroe 2001) (Amended Flow-Chart, Step 6).

\section{Step 9: Analysis of Results}

The information collected from both data sheets and surveys was not robust enough to generate any statistically significant analysis. Relevant results and useful insights will be discussed in chapter 6 . 


\section{Chapter 6: Discussion}

Results from the surveys are not statistically robust, but still provide useful information to the future of the briquette program. The purpose of this report is to examine briquette use in combination with improved stoves and community acceptability of both improved alternative technologies. Responses relevant to acceptability and pricing are used to draw conclusions in this chapter. Results are from six (6) period-two surveys.

\section{Acceptability}

The limited responses show a high level of acceptability. One hundred percent of respondents said they would use and purchase briquettes in the future and recommend both technologies to friends. Five out of six said the improved stove was best cooking method for briquette use. The sixth respondent had only used the improved stove so had no comparison, but still thought the briquettes worked well in the stove.

\section{Synthesis of Information}

Information from the structured, open-ended surveys was synthesized to make recommendations that would be useful to the Dinsho project and related projects in the future. When I began the trials I had lived as a member of the 
community for over one and a half years and respondents were comfortable discussing their thoughts and opinions with me, so my analysis is led by a participant observer approach (Bernard 2002). The lessons learned vary depending on the context. Lessons learned came by examining my project from the Ethiopian context and overcoming technical problems.

\section{Perceived Barriers, the Ethiopian Context}

"Why did this project not go according to plan?" There is no one easy answer. The most difficult problem I faced was the valuation paradigm of the Ethiopian context. I had my own perceptions of the value of the project and on more than one occasion these did not match the values of the community members. Two valuation schemes with which I was at odds were the value of words and material resources.

Seeing through and beyond the language is the most difficult part. As a Peace Corps Volunteer my primary challenge was communication in two Ethiopian languages. I became proficient enough to hold simple conversations and conducted my project in clear language that was straight forward, but what I found, and should have expected, was that verbal agreement or validation does not mean action.

Ethiopians pride themselves on being good hosts. They want to make their guests happy even if that means forcing food and drink upon guests well beyond refusal. To have an unhappy guest is a point of personal shame. Even though I 
was treated as a member of the community I was still a guest, which turned me into an honored guest. I was constantly amazed at people's desire to ensure my comfort and happiness, but this did not translate well into association establishment or data collection. People wanted to ensure my happiness, especially at the cost of real productivity. I do not mean to call Ethiopians fabulists, but there is a difference in paradigms. They say, "Yes, I understand." "Of course I can do that for you." and genuinely mean it, and they may have best intentions to follow through with the agreement, but in their lives there are many other things that trump putting a hash mark on a piece of paper every time you use a briquette. This trend of people saying they will do some task and then not following through extends to commitments made to all people, not just guests, foreigners or expatriates.

Beyond verbal communication the spoken word carries different values and these differing values change, in a way, the interpretation of what is meant. To me I see the value of our agreement based on the outcome, or results of the agreement. For example, me; "I want to interview you about your farm on Monday after the market. Can we meet then?” Respondent: "Yes we can meet then. I am looking forward to our meeting." To me the value is in the results of the interview about the farm while for the respondent the value is being able to say "Yes" to my question and the social value they perceive in spending time with me and making sure I am not upset. When it comes time for him or her to make the choice of whether or not to come and meet me in town for the interview the 
respondent is not valuing my research or keeping his or her word. He or she is instead valuing the importance of the social interaction and if there is something more pressing than simply looking good by being seen in town with the farenji, white person, then the interview is secondary. In the developing world there are many more important things to worry about for host country nationals than some questions that a foreigner is asking. Development workers should always be aware of the contextual value of words and build expectations accordingly.

Material resources have only a perceived value if money or trade is directly involved. While establishing supply lines for materials three examples of value differences became apparent including the value of communication. Sourcing materials is paramount to the success of briquette manufacture. Coffee husks, eucalyptus leaves, and paper were all being treated as a waste product with no real value and where others saw a nuisance I saw an opportunity.

Eucalyptus leaves were collected from the plantations outside of Goba town and processed for their oil. After the oil was distilled the leaves were simply thrown into piles and, after long periods of accumulation, were burned. Getting permission to utilize these and set a collection schedule to feed the briquette project proved difficult. To those processing the leaves the piles were a nuisance and got in the way of oil production and other income generation activities. To me they were a valuable resource and utilization seemed simple. My first inquiry about their availability and permission for use was met with skepticism and confusion. Once they realized that someone valued their waste, they delayed 
granting permission for over two months. I was told that someone else wanted them, which turned out to not be the case. They may have been waiting for a bribe. After two and a half months I received permission to collect leaves. When I arrived to collect them the leaf piles were burning. Either there had been no communication or miscommunication. Following further meetings and emails we finally came to an agreement that the waste leaves were not to be burned and could be picked up regularly.

Development workers attempting a briquette project, or any project, should be aware of how people value the materials, consider the methods for acquiring them, use appropriate methods of communication as much as possible, and build the lines of communication personally. Development work attempts to link organizations with similar or related goals for mutual success. Communication is paramount to multi-organization project success. There are the two extremes of "hands off" institutional capacity building for long-term success and "hand holding" for short-term success. Each situation will be different depending on the goals of the project and timeframe. OFWE and FZS had worked together in the past with success and I assumed their partnership would be strong enough to help my project. This was not the case. With this new project and I should have taken greater responsibility for communication to get the project started. Development workers will need to determine for themselves what level of involvement is right in their context.

In the Ethiopian context, people in positions of authority will use their 
influence and clerical formalities to exercise power. All projects or agreements must be printed, signed and have a purple stamp. Without a purple stamp no document is valid. Even with a purple stamp people may refute whatever the document says. In my case documents were channeled through the hands of three or four different individuals who each reported inconsistent responses from the organizations or offices involved, creating confusion between all parties. I should have personally delivered all documents.

I recommend development workers investigate and understand the cultural norms in their project area and become personally engaged with all active members and organizations during project start up to identify possible weaknesses. It can be difficult for development workers to find a balance between too much involvement or aid and letting host country organizations work together for a projects success. Development workers attempt to build capacity of host country nationals and organizations, but they must be aware of when to take matters into their own hands and when to let go.

\section{Applications for Development Workers}

Briquette manufacture is a labor-intensive process. Materials collection, physical breaking down or crushing and partial decomposition to loosen the natural fibers of those materials are jobs that need daily attention. The most basic method of physical breakdown of materials is by hand or mortar and pestle. Both methods constrain the volume and pace of production. I recommend 
securing mechanization or manual alternatives and proper equipment for processing materials, reducing labor requirements.

Virginia Echavarria found similar labor problems with her projects in the Democratic Republic of the Congo (personal communication). She recommended the use of a hammer mill. The cost of hammer mills or cassava mills with an adjustable screen size can be prohibitive, but are fairly common in most large cities. Electric and manually operated versions of hammer mills are available. Capital and fund raising would be the main barriers to mechanization.

Free gifts from aid sources can hinder project sustainability once aid is gone. If initial investment can make the project profitable and sustainable over time then it is worth the investment of mechanization. Development workers should ask the question, "How long will the initial investment allow the project to operate without equivalent reinvestment?" This could be thought of as investment sustainability. Will the investment be adequate to sustain the project over time or will it create a weakness, relying on outside aid?

Mill durability would be important when evaluating investment sustainability. Mills with a long life could be a good investment from an outside organization. Mills that would require continual maintenance or replacement after initial aid is gone becomes the problem of the briquette organization. Building capacity under these circumstances for self-reliance is mandatory for project sustainability. One approach would be for briquette manufacture to begin with mortar and pestle while saving to purchase a mill. The organization would 
then know how to save money for future mill repair or replacement.

Acquiring screens is recommended for two reasons: improve quality control by limiting particle size and to reduce labor intensity of manually removing debris. Briquette pressing can be slowed because of irregular or large pieces of wood chips or other foreign objects in the briquette mixture.

Shredded paper is preferable to non-shredded. Paper that is shredded or torn into small pieces makes pulping faster and more uniform. The amount of paper that can be shredded by hand was a limiting factor to how many briquettes could be pressed in a day. For pulping paper I recommend using two 100-liter containers. This would allow for day-to-day rotation using pulp from one container while the other is refilled for the next day.

Schools are a great source of paper for a briquette project. In the schools waste, including paper, is collected and then burned about once per month. I set up paper collection through one meeting with teachers and the result was bags of rubbish that included paper. My desire for just paper was lost in the communication chain. Greater involvement on the part of briquette manufacturers could help avoid this issue, saving sorting labor in the long-term. This would also provide an opportunity for environmental education in the schools and perhaps encourage schools to start their own briquette programs. Schools that have nature or environmental clubs could produce and sell briquettes to raise money for club activities such as tree planting events. Integration into the community may generate responses and reactions to a 
project that seem positive at first, but say nothing about the long-term success of the project. A behavioral pattern that I and FZS found is people want what is seen as new and exciting, or as a free hand out. Once trials were running, word spread about the new stove and new fuel briquettes. They became social status items. It became a point of tension between the project and my friends and neighbors. Some would get upset, asking why I had not given them or their mother a stove and briquettes yet. People took personal offense that I had not given them a "gift" of briquettes or stove. Anyone starting a similar project should keep in mind the effects that being a community member can have on the project and its effects on your personal relationships. If the purpose of the project is to collect data for analysis I recommend trying to work outside of your community. This would reduce biased responses and remove social pressure.

\section{Fuel Briquette Project Recommendations}

In a location such as Dinsho where raw materials may be scarce or out of reach for sociopolitical reasons I recommend diversifying materials as much as possible. Many briquette projects use two or three ingredients, but if the location is biomass poor, think variety. Recipes with four or more ingredients give the briquette maker a chance to experiment and allows for flexibility. If one material were limited or seasonal, a greater variety of ingredients would give a project greater flexibility and resiliency.

Coffee husks should be carbonized and or crushed. GIZ's research leaned 
toward carbonization, but if carbonization is too costly I recommend crushing. I kept costs down by using a mortar and pestle, but recommend acquiring a mill if available and funding allows. A mechanical mill, such as a hammer mill is recommended.

All materials should be screened for a uniform size. Binding materials should be screened prior to decomposition and filler materials prior to mixing. Often I would pick large pieces out of the slurry as I mixed and poured. Materials that are not broken down or screened appropriately create weaknesses in briquettes. Screening materials would improve overall briquette quality and quality control.

Smoke production should be considered for two reasons: acceptability and air pollution. The most frequent comment offered by respondents without prompting was smoke production. Some respondents preferred to light the stoves outside and move them into the home or kitchen once the initial smoke decreased. I recommend carbonization of filler products when cost is not a prohibitive factor.

If a briquette project is being carried out in a cold location like Dinsho, 6 $-15^{\circ} \mathrm{C}$ (World Weather Online 2013), the use of a composting pit may be necessary. A composting pit should be long and narrow, roughly $10 \mathrm{~m}$ long by $1.5 \mathrm{~m}$ wide and $0.5 \mathrm{~m}$ deep. As materials for a day of briquette work are removed from one end all materials would be turned over, moving them farther down the line, thereby creating an open space at the opposite end for 
the addition of new materials.

A recommendation for further study is how to accurately determine the amount of fuelwood use offset by briquette use. I intended to weigh fuelwood before and after each three-day trial. These data were to be averaged with fuelwood use responses provided in the surveys and compared to the number of briquettes used to price briquettes for sale. Pricing information would allow associations to create a break-even analysis and make projections to guide business decisions. During the first trial it became apparent that this method would not work. Illegal harvesting and irregular fuelwood collection and purchase schedules meant that trial periods and fuel purchases were on different time lines, making it difficult to accurately measure household consumption.

There are five species of wood used as firewood in Dinsho; eucalyptus, Erica arborea, E. trimera, Juniperous procera, and Hagenia abyssinica. Eucalyptus is planted in either small woodlots or as boundary plantings and are regularly used for building poles and firewood. Juniperous and Hagenia are harvested from both inside and outside the park. These two species are harvested by splitting off vertical sections of the bole while standing. Over time the trees die and become easier to fell. Vertical splitting is women's work and felling is men's work but collection and transportation is generally children's work. Erica species are of greater concern to the EWCP, FZS and the Park. They grow in altitudinal belts above the Juniperous and Hagenia 
tree line and have slow regeneration rates and poor reproduction success under current pastoral pressure. Harvesting of Erica species is primarily the work of children who hike several kilometers into the mountains to cut and let dry small diameter sticks. After a period of time they return and collect the dried bundles. As time passes the harvest line moves further into the mountains forcing children to walk farther for harvesting (Figure 3.3).

Legal fuelwood was sold during two market days per week, but illegally harvested wood could be bought any day of the week and I suspected that several of the respondents were illegally collecting from the park. Questions about fuelwood use, source, and purchasing were answered with caution, skepticism and inconsistent answers. I often had to defend myself, reiterating that I was not asking questions on behalf of the Park or any other organization.

\section{Cost Effectiveness}

I relied on respondent estimates of fuelwood and money savings to calculate an appropriate price for the briquettes. Mean value of money saved per briquette was 0.88 birr. When compared to mean willingness-to-pay of 1.08 birr, the perceived value of the briquette is higher than actual money saved. To calculate a recommended price I chose to use median values because of the large values of three birr per briquette and fifty four birr saved. Median willingness-to-pay is 0.75 and money saved per briquette is $0.78 \mathrm{birr}$. I recommend a price and 
minimum selling quantity is twelve briquettes for nine birr, 0.75 birr each. At this price the briquettes are lower than willingness-to-pay and the cost of an equivalent amount of wood making it a competitive fuel alternative. Pricing responses are in Table 6.1.

Table 6.1: Pricing responses for willingness to pay for briquette and stoves and estimated birr saved in fuelwood reduction.

\begin{tabular}{lccc}
\hline Respondent & Briquettes (birr) & Stoves (birr) & Savings (birr) \\
\hline 1 & 1 & 60 & 25 \\
2 & 0.5 & 100 & 25 \\
3 & 0.5 & 200 & 54 \\
4 & 3 & 200 & 25 \\
5 & 0.5 & 50 & 10 \\
6 & 1 & 50 & 30 \\
Totals & 6.50 & 660 & 169 \\
Mean & 1.08 & 110 & 28.17 \\
Median & 0.75 & 80 & 25 \\
\hline
\end{tabular}

\section{Stove Project Recommendations}

My recommendation for NGOs and development groups is to develop more flexible and appropriate stove designs. Many designs I came across while researching were inappropriate. Specialized materials like stoneware ceramics and galvanized steel might be good for product development but not 
for field applications. A focus on how to adapt locally available materials and methods that do not require specific training or expensive equipment is needed. The molds I designed were made for $\$ 115$. This was slightly more expensive than I would have liked but considering it was a custom experimental product, $\$ 115$ is acceptable, especially with the large budgets of some NGOs and development groups. The molds were designed for construction using local clay, which allows for local adaptability in the specific ceramic mixtures used.

One complaint about the stoves was non-compatibility with charcoal. This was intentional, but in hindsight, creating a stove that would allow for a greater amount of fuel diversity may prove to be more acceptable. Creating a stove that could burn charcoal, wood or briquettes efficiently would be ideal instead of trying to introduce a new stove that burned only a new fuel type. When introducing a new and or transitional technology being as user friendly and familiar as possible will help improve its acceptability.

\section{Respondent Creativity}

The most surprising response to this project was respondent creativity with briquette and stove use. I instructed respondents on how I intended the briquettes and stoves to be used, but soon into the first survey period I found the preferred method of stove use was with mixed fuels. I provided each stove with a fuelwood shelf to encourage its use as a fuel-efficient wood stove. This 
was to determine if they preferred to use the stove as a wood burning or briquette stove. Instead many of them used both fuel sources. Wood was used in the bottom to get the stove burning and then briquettes, either whole or broken into pieces, were fed into the top of the stove. I incorporated this method in my training and it quickly became the preferred method. Respondent creativity taught me a method of use that I would not have thought of on my own. I recommend that briquette projects use this fuel diversification route. 


\section{Chapter 7: Conclusion}

I had hoped to collect statistically sound data that would tell me whether or not the introduction of an improved stove would affect the acceptability and success of a biomass fuel briquette project. Many difficulties derailed the initial plan, but valuable lessons were learned. Insights into briquette projects in cool climates similar to Dinsho, $6-15^{\circ} \mathrm{C}$, and adjustments that should be made, the value of ingredient diversification, importance of local ingenuity, fuel diversification, social constraints, and briquette valuation will be useful to people implementing briquette and stove projects.

Despite the difficulties, respondents and other community members liked both new technologies. One respondent was a tea shop owner. As we would sit outside going over data sheets and surveys or discussing the day's work we would draw a crowd of interested community members. When asked, "What do you do here?" I would start public discussions about my project, showing people samples or drawings. It might take a lengthy discussion but eventually most people were interested in the project and many times called the project gobez or chimaa, clever in Amharic and Oromifa. By the end of my time in Dinsho I could not have made stoves or briquettes fast enough to supply the public demand. I could not go into town without being harassed for more stoves and more briquettes. There have been other stove projects in Dinsho in the past and one respondent added to the survey that she thought the stove was the most important stove she had ever seen, but beyond the 
initial response there are many other economic and social implications and considerations.

\section{General Framework for Briquette and Stove Development}

This report discusses aspects of the briquette and improved stove project that are very specific to Dinsho, but more general conclusions can be made that would translate to projects in other locations and provide a recommended framework for others to follow who desire to start a briquette or improved stove project separately or simultaneously. Figure 7.1 is a general framework based on my recommendations. The recommended framework is similar to the initial project framework.

There are a few assumptions and changes however. The first assumption is the development worker starting this project has already established the community's need for such a project. With community need, there will be a difference in initial buy-in if the community itself, governmental body, or NGO recognized and evaluated this need. Also, the parties responsible for each step and methods of communication and multi organizational cooperation may change. This framework is designed to help increase transparency and communication from the first step.

The design of this framework is intended to be sequential. There are no date or time dependent restraints, but a sequential requirement. A sequential 


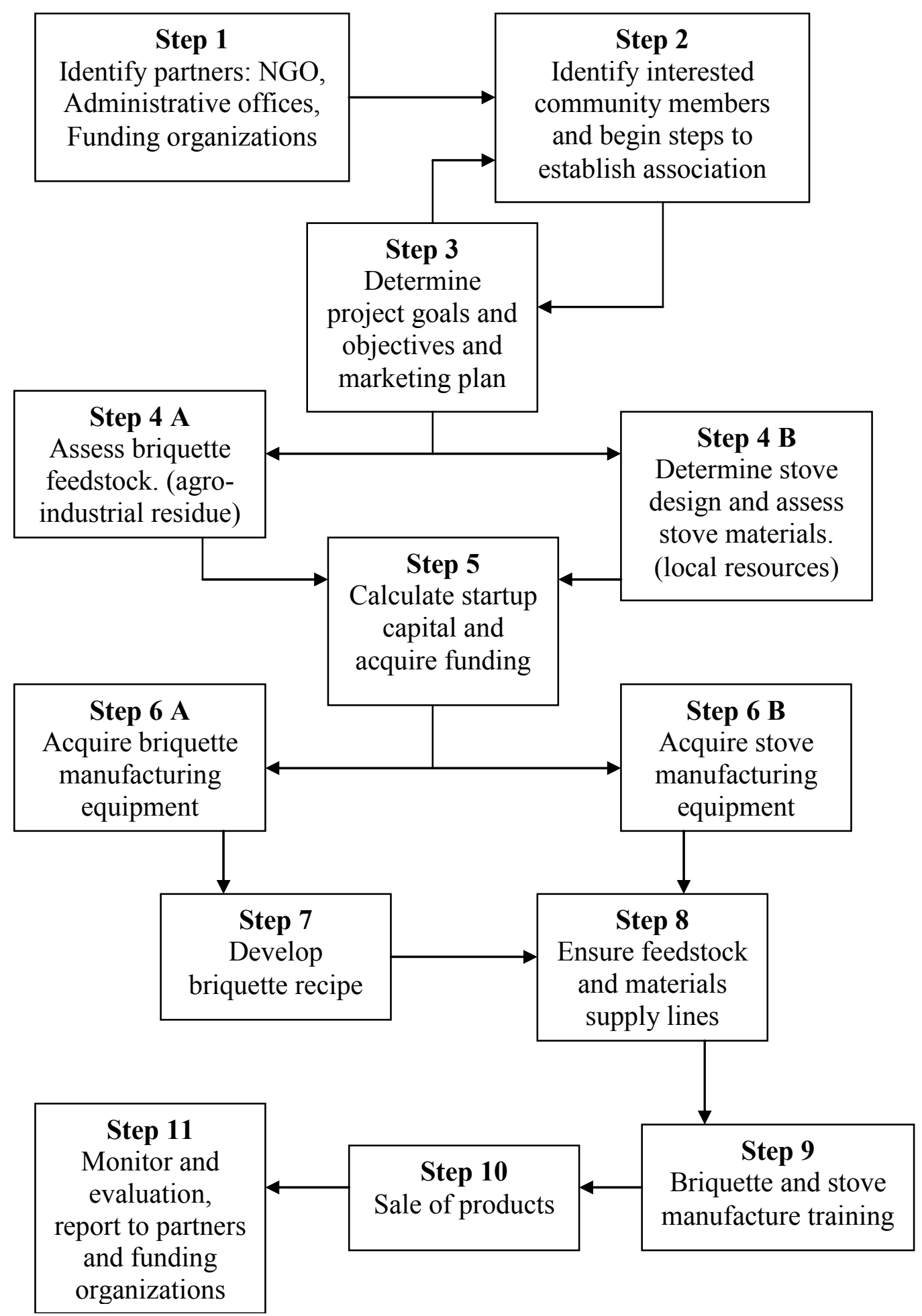

Figure 7.1: Recommended project framework. 
requirement helps ensure time and resources are not wasted and that each new step is a "reward" for successful completion of the previous step. This approach can improve sustainability by allowing initial community-wide involvement and letting the process become one of self selection (Orr 1986). After the first few steps the project should be able to tell the difference between those who are truly interested and motivated and those who were involved for the novelty of the project. If self-selection does not occur it could be the responsibility of the development worker to evaluate performance along the way and make appropriate personnel changes. Feedback and communication with partners and funding bodies is recommended throughout the process.

\section{Step 1}

The first step is identifying all groups and organizations that may be involved, interested in or a possible source of capital funding the project. Sit-down meetings with each group separately or together will help each group and the project leader decide their level of involvement and how they may be helpful to the project either with technical, administrative or financial assistance. 


\section{Step 2}

Once partner organizations have met to discuss project involvement and support the next step is identifying interested community members and beginning the process of association establishment. This step will rely upon the locations legal requirements for the establishment of a new association. For example, in Dinsho, the administrative office was legally required to post public announcements for job vacancies for staffing. In such a case the development worker could identify individuals who are interested and motivated and help them through the application process to encourage their inclusion into the association.

With members hired, the formal steps of association business planning, operations, management, and bylaws can begin. Business training at this level should be a step-by-step approach that includes budgeting, capital investment, break-even analysis, savings and reinvestment to improve sustainability. If there are several NGOs that offer business-training packages, they should have been identified in step one.

\section{Step 3}

With the initial group of association members selected, the first decision they need to make is whether they will produce briquettes or 
stoves or both, as this will guide association objective and decisions. Once the products are chosen a marketing strategy and plan should be developed as part of the association's foundations. The most basic question to ask for this step is, "What are we selling and to whom?" The answer to this question will guide the association into steps $4 \mathrm{~A}$ and or 4 B.

\section{Step 4 A}

The next step, if the association decides to produce briquettes, is identifying possible feedstock and assessing the appropriateness of each one. Once feedstock types are chosen, collection can begin.

\section{Step 4 B}

If the association decides to produce stoves, an appropriate design should be selected and appropriate materials will need to be identified, focusing on local availability and manufacture.

\section{Step 5}

Depending on the products chosen for manufacture, materials and feedstock sources in step 4 A and B, a total value for startup capital should be calculated and adequate funding obtained. This could include grants, gifts, fundraising projects or micro-loans. 


\section{Step 6 A and $B$}

With adequate funding obtained, all equipment for association operations should be purchased.

\section{Step 7}

Once all manufacturing equipment, materials and feedstock obtained, experimentation can begin to determine the optimum briquette recipe. The Legacy Foundation manuals should be used for this step as well as the modified Water Boiling Test to determine briquette performance.

\section{Step 8}

With briquette and or stove materials and manufacture practices determined, the reliability of feedstock and materials supply lines should be secured before full-scale production begins. Meetings with each partner and supplier should clarify the future of the project and intentions. Feedstock and materials cost should be negotiated if necessary. Contracts should be produced for each organization whether or not materials are purchased. 


\section{Step 9}

Once feedstock and materials supply lines are ensured, training can begin for full-scale production. The Legacy Foundation Manuals should be consulted for briquette manufacture.

\section{Step 10}

Once production has begun briquettes and or stoves can be made available for sale, utilizing the marketing strategy outlined in step three.

\section{Step 11}

As the association begins production and selling their products monitoring and evaluation of association operations should be conducted. Results should be reported to all initial partner organizations. Most funding organizations will require this step. Monitoring and evaluation should be repeated to improve association sustainability.

While the initial diagram (Figure 5.2) was designed for a research and development project this series of steps is developed for business or association development. There is an increase in cross-organizational communication, feedback and transparency and participant self-selection. 
Another difference between a research approach and a business approach is the requirement for sequential progression. In the development context it almost impossible to put strict dates or timeframe to any of the steps due to unexpected barriers that will be encountered along the way, but sequential requirement ensures that future materials and labor will not be wasted. If an association can follow the step-by-step framework there would be a greater chance for project sustainability once development workers and partner organizations pull out.

\section{Economic Viability}

Development projects, especially one with an income generating component, must be economically viable to be successful and sustainable. The World Bank reported a Gross Domestic Income per capita of only $\$ 370$ in 2011. By current exchange rates the average daily per capita income is 18.67 birr per day, just over one dollar. This is a national average however and in rural areas the average daily income is closer to 15 birr per day (FZS 2007). TLF materials suggest a high volume briquette operation could produce 1000 briquettes daily. With my experience I think that an association in the startup phase, 500 briquettes per day is a more realistic number. At the recommended selling price of nine birr for twelve briquettes, that makes the association daily gross net income 375 birr. Eight to six employees would gross 46.88 to 62.50 birr per day. This would be an increase in average daily 
income of three to four times the national average. At these rates the opportunity for personal livelihood enhancement are great, but the project would need to consider the issue of capital and reinvestment savings.

For this project briquette feedstock was free. This project made feedstock suppliers view their waste materials differently. The interest of an association in an industry's waste product will cause a shift in material value and associations should expect these costs. The management, operations and bylaws of any new association should include the long term effect of this value change and adjust their business plan accordingly. Savings and petty cash should be set aside for equipment and feedstock purchase. In the case of this project, the OFWE managers may eventually begin charging for the eucalyptus leaves. Profit forecasts and break even analysis should include these expenditures and adjust briquette cost and association member incomes to ensure economic feasibility. Along with the cost of feedstock, reinvestment capital savings plan should be included in association operations, especially in the case of expensive equipment, such as mills. If the association's business plan is well thought out all input costs will be covered and association's members would still have higher than average incomes.

Briquette and improved stove projects could also play an integral role in managing conflict between the Park, communities within the Park and those surrounding communities whom the park is an "open resource". Fuelwood harvesting is a threat to the fragile habitats in and around the park. 
FZS and Park staff over the past six years has increased enforcement of the fuelwood prohibition. For some people, fuelwood collection may be a significant, if not primary, source of income. With effective enforcement, more and more people will lose income. This has and will continue to strain the relationship between Park and FZS staff and community members. One option would be to hire fuelwood collectors for briquette materials collection. Instead of just removing a source of income there could be a materials or livelihood shift that allows for continued income generation.

In the past, communities along the road leading into the Bale Mountains would cut both Juniperous and Hagenia and sell it in bundles along the road side. FZS Community Liaison Officers and Scouts, through repeated engagements, put a stop to this behavior and in turn worked with the communities to establish Participatory Forest Management sites, which did not always receive community support. Changing the material (e.g. from wood to leaf litter) being collected and sold would be less of a stark change in behavior. The same fuelwood collectors could be trained in briquette feedstock collection. The feedstock could be picked up from previous fuelwood sale sites along the roadside or taken to the briquette manufacturing site. Analysis would need to be carried out as part of the economic feasibility study to determine how many individuals this type of materials collection scheme could support so as to not create a rush of materials collectors flooding the market. As the briquette project grew it could then incorporate 
and support more materials collectors. The briquette association would be supporting a network of materials sub-contractors, relieving the association members of a majority of materials collection labor. This approach would provide a more diversified income source for these rural poor, increase utilization of non-timber forest products and help an association with steady

growth, producing greater amounts of briquettes, reduce fuelwood consumption, mediate Park-community tension, and improve project sustainability.

\section{Summary}

What is this project's long term impact? Can the small introduction of a simple new or transitional technology have a positive overall effect in terms of development goals? The introduction of these two technologies on such a small level and focusing on adoptability and acceptability can begin, at the local level, changes to improve quality and quantity of livelihood. With this projects success multiple levels of development would take place: habitat protection for endemic and endangered species, forest conservation, carbon sequestration, watershed protection, soil protection, indoor air pollution reduction, income generation, utilization of NTFPs, and protected areascommunity conflict mitigation. Even gender and inequality issues can be addressed; women are responsible for fuelwood collection and suffer most of the negative health consequences of indoor air pollution. Nobel Laureate 
Joseph Stiglitz writes "When you have a little innovation like this, it changes the well-being of one part of the society that in many developing countries is very oppressed...But a good environmental policy like this one [efficient cook stoves] can have very big effects on equality." (Stiglitz 2013). Small community based projects may at first only seem like a drop in the pond but the ripple effects could be broad reaching. A briquette project may start as an income generating enterprise for six to ten people but with expansion and feedstock sourcing tens of individuals including men, women and children could begin to profit from a single enterprise.

Highland forests of Ethiopia and Bale Mountains are in need of protection. Projects such as this are an important tool for conservation efforts. Finding pathways that combine conservation, income generation, NTFP utilization, and education should be promoted in and around the remaining forested areas of Ethiopia. It is up to the Ethiopian people whether remaining forests are available for future generations. Conservation efforts must include education and new and appropriate technologies to build capacity for Ethiopians to take control of their natural resources and carry on their culture as they have for millennia. 


\section{Works Cited}

Aprovecho Research Center, Testing and Protocols. (2009).

http:www.aprovecho.org/lab/pubs/testing. (accessed December 2011).

Arnold, J.E. Michael, and M. Ruiz Pérez. "Can non-timber forest products match tropical forest conservation and development objectives?" Ecological Economics 39, no. 3 (2001): 437-447.

Awulachew, Seleshi BekeleYilma, A. D. Loulseged, M. Loiskandl, W. Ayana, and T. M Alamirew. "Water resources and irrigation development in Ethiopia." Vol. 123. Iwmi, 2007.

Bernard, H. Russell. "Research methods in anthropology: Qualitative and quantitative approaches." Altamira Press, 2002.

Bishaw, Badege. "Deforestation and Land Degredation in the Ethiopian Highlands: A Strategy for Physical Recovery." Northeast African Studies 8, no. 1 (2001): 7-25.

Britenbach, F. Von. "Forest and woodlands of Ethiopia." Ethiopian Forestry Review 1 (1961).

Camberlin, Pierre, and Nathalie Philippon. "The East African March-May rainy season: Associated atmospheric dynamics and predictability over the 1968-97 period." Journal of Climate 15, no. 9 (2002): 1002-1019.

C.I.A. (Central Intelegence Agency). The World Factbook: Ethiopia, https://www.cia.gov/library/publications/the-world-factbook/geos/et.html. (accessed February 2013).

Dejene, Alemneh. Integrated natural resources management to enhance food security. Organisation des Nations Unies pour l'alimentation et l'agriculture, 2003.

Denzer, Kiko, and Hannah Field. "Build your own earth oven." (2000).

DIVA-GIS. http://www.diva-gis.org/gdata. (undated) (accessed April 23, 2013).

Ethiopian Embassy. "Investing in Ethiopia."

http://www.ethiopianembassy.org/AboutEthiopia/AboutEthiopia.php?Page= InvestingInEthiopia.htm. (accessed March 3, 2013). 
FAO. "Global Forest Resources Assessment 2010, Country Report: Ethiopia." Food and Agricultural Organization of the United Nations, 2010.

Feyisa, Taye Hailu, and Jens B. Aune. "Khat expansion in the Ethiopian highlands." Mountain Research and Development 23, no. 2 (2003): 185-189.

Frankfurt Zoological Society. "Bale Mountains National Park General Management Plan." 2007.

Hess, Robert L. Ethiopia: the modernization of autocracy. Vol. 2. Ithaca: Cornell University Press, 1970.

Holey Rocket Stove, Biomass Briquette Stoves Library. (undated). http://briquettestoves.com/holey-rocket/, (accessed March 17, 2013)

Kassa, Habtemariam, Berihun Tefera, Girmay Fitwi, H. Kassa, B. Tefera, and G. Fitwi. Preliminary value chain analysis of gum and resin marketing in Ethiopia. CIFOR, 2011.

Kloos, Helmut, and Aynalem Adugna. "The Ethiopian population: growth and distribution." Geographical Journal (1989): 33-51.

Korecha, Diriba, and Anthony G. Barnston. "Predictability of June-September rainfall in Ethiopia." Monthly Weather Review 135, no. 2 (2007): 628-650.

Land Below Sea Level. www.geology.com/below-sea-level. (accessed February 2013).

Lemenih, Mulugeta, and Fisseha Itanna. "Soil carbon stocks and turnovers in various vegetation types and arable lands along an elevation gradient in southern Ethiopia." Geoderma 123, no. 1 (2004): 177-188.

MacCarty, Nordica, Dean Still, Damon Ogle, and Thomas Drouin. "Assessing Cook Stove Performance: Field and Lab Studies of Three Rocket Stoves Comparing the Open Fire and Traditional Stoves in Tamil Nadu, India on Measures of Time to Cook, Fuel Use, Total Emissions, and Indoor Air Pollution." Aprovecho Research Center (2008).

McCann, James C. "The plow and the forest: Narratives of deforestation in Ethiopia, 1840-1992." Environmental History 2, no. 2 (1997): 138-159.

McClanahan, Tim, and Truman P. Young. East African ecosystems and their conservation. Oxford University Press, USA, 1996. 
McKee, Jonathan. "Ethiopia country environmental profile." EC Delegation, Addis Abeba (2007).

Million, Bekele, and Berhanu Leykun. "State of forest genetic resources in Ethiopia." Forest Genetic Resources Working Papers (2001).

Mohammed, M. U., and R. Bonnefille. "A late Glacial/late Holocene pollen record from a highland peat at Tamsaa, Bale Mountains, south Ethiopia." Global and Planetary Change 16 (1998): 121-129.

Mohr, Paul A. The geology of Ethiopia. Vol. 270. University College of Addis Ababa Press, 1963.

Monroe, Martha C. "Evaluation's Friendly Voice: The Structured Open-Ended Interview." Applied Environmental Education and Communication 13 (2001): 18.

Ofcansky, Thomas P., and LaVerle Berry. "Ethiopia a country study." Kessinger Publishing, 2004.

Orr, B. "Refugee forestry in Somalia." Rural Sociologist 5, no. 4 (1985): 267272.

Petit, Nicolas. "Ethiopia's Coffee Sector: A Bitter or Better Future?." Journal of Agrarian Change 7, no. 2 (2007): 225-263.

Reusing, Matthias. "Change detection of natural high forests in Ethiopia using remote sensing and GIS techniques." International Archives of Photogrammetry and Remote Sensing 33, no. B7/3; PART 7 (2000): 12531258.

Seleshi, Yilma, and Ulrich Zanke. "Recent changes in rainfall and rainy days in Ethiopia." International Journal of Climatology 24, no. 8 (2004): 973983 .

Stephens, Philip A., Candy A. d'Sa, Claudio Sillero-Zubiri, and Nigel LeaderWilliams. "Impact of livestock and settlement on the large mammalian wildlife of Bale Mountains National Park, southern Ethiopia." Biological Conservation 100, no. 3 (2001): 307-322.

Stiglitz, Joseph E. "Inequality and Environmental Policy."Resources No. 182 (2013): 36 . 
Still, Dean, Mike Hatfield, and Peter Scott. "Capturing Heat Two." Aprovecho Research Center, Cottage Grove, OR 97424 (2000).

Taddese, Girma. "Land degradation: a challenge to Ethiopia." Environmental Management 27, no. 6 (2001): 815-824.

Taffesse, Alemayehu Seyoum, Paul Dorosh, and Sinafikeh Asrat. "Crop production in Ethiopia: regional patterns and trends." Ethiopia Strategy Support Program II (ESSP II) Working Paper 0016 (2011).

The Legacy Foundation. "Fuel Briquettes: Theory and Applications from around the World." (2003a).

The Legacy Foundation. "Fuel Briquette Making A Users Manual." (2003b).

U.N. Forum on Forests. "Report of the Eighth Session (27 April 2007 and 20 April to 1 May 2009)." Economic and Social Council, Official Records, Supplement no.22 (2009).

U.N.-OCHA. "Digital Elevation Model." (2006).

http://www.unocha.org/eastern-africa/maps-graphics/ocha-

maps?page $=1 \mathrm{htm}$.(accessed March 5, 2013).

U.N. Statistical Division. "Environmental Indicators." 2010.

http://unstats.un.org/unsd/environment/qindicators.htm. (accessed February 3, 2013).

Van Den Berg, Marrit, and Girma Earo Kumbi. "Poverty and the rural nonfarm economy in Oromia, Ethiopia." Agricultural Economics 35, no. s3 (2006): 469-475.

Watson, Charlene, E.J. Milner-Gulland, and Susan Mourato. "Direct consumptive use valuation of ecosystem goods and services in the Bale Mountains Eco-region, Ethiopia." PhD diss., MSc Thesis. Imperial College London, Centre for Environmental Policy (2007).

World Bank. "Agricultural Land (\% of land area)." http://data.worldbank.org/indicator/AG.LND.AGRI.ZS (accessed on March 26, 2013).

World Bank. "World Development Report 2004: Making Services Work for Poor People." Oxford University Press, 2003. 
World Weather Online. http://www.worldweatheronline.com/, (accessed March 15, 2013).

XE Currency Converter. http://www.xe.com/currencyconverter/convert/? Amount=1andFrom=USDandTo=ETB. (accessed on February 27, 2013). 


\section{Appendix 1}

\section{Permission for use}

1. Figure 2.1. Map of Ethiopia and surrounding countries.

Unless a copyright is indicated, information on the Central Intelligence Agency Web site is in the public domain and may be reproduced, published or otherwise used without the Central Intelligence Agency's permission.

https://www.cia.gov/about-cia/site-policies/index.html\#copy. (accessed January 16, 2013)

2. Figure 2.2. Administrative and topographic map.

The United Nations maintains this web site (the "Site") as a courtesy to those who may choose to access the Site ("Users"). The information presented herein is for informative purposes only. The United Nations grants permission to Users to visit the Site and to download and copy the information, documents and materials (collectively, "Materials") from the Site for the User's personal, non-commercial use, without any right to resell or redistribute them or to compile or create derivative works therefrom, subject to the terms and conditions outlined below, and also subject to more specific restrictions that may apply to specific Material within this Site.

http://www.unocha.org/eastern-africa/maps-graphics/ochamaps?page $=1 \mathrm{htm} .($ accessed March 5,2013$)$ 


\section{Appendix 2}

\section{Briquette Survey 1 \\ Qu'achuu xuubii boba'aa toko}

Kebele:

Woreda:

Date:

Survey Questions:

1. Of the cooking methods you used briquettes with, how easy did you find each to light on a scale of $1-5$, with 1 being impossible and 5 being easy?

\begin{tabular}{|c|lllll|}
\hline Midijja & 1 & 2 & 3 & 4 & 5 \\
\hline Dhagaa sadii & 1 & 2 & 3 & 4 & 5 \\
\hline
\end{tabular}

2. Once lit which was the easiest to keep burning? Rate on a scale of 1 to 5 , with 1 being that it could not be kept lit and 5 being the easiest to keep burning.

\begin{tabular}{|c|lllll|}
\hline Midijja & 1 & 2 & 3 & 4 & 5 \\
\hline Dhagaa sadii & 1 & 2 & 3 & 4 & 5 \\
\hline
\end{tabular}

3. For each cooking method rate the following on the $1-5$ scale. 1 being no smoke and 5 being the most. Circle one.

Amount of smoke produced

\begin{tabular}{|c|lllll|}
\hline Midijja & 1 & 2 & 3 & 4 & 5 \\
\hline Dhagaa sadii & 1 & 2 & 3 & 4 & 5 \\
\hline
\end{tabular}

Length of one briquettes burn

\begin{tabular}{|c|lllll|}
\hline Midijja & 1 & 2 & 3 & 4 & 5 \\
\hline Dhagaa sadii & 1 & 2 & 3 & 4 & 5 \\
\hline
\end{tabular}


4. Which cooking method do you feel the briquettes are best and least suited for? Rate them 1 to 3 with 1 being the worst and 3 being the best.

\begin{tabular}{|c|c|}
\hline Midijja & \\
\hline Dhagaa sadii & \\
\hline
\end{tabular}

5. How would you rate the briquettes overall performance on a scale of $1-5$, 1 being the worst performance and 5 being the best.

\begin{tabular}{|lllll}
1 & 2 & 3 & 4 & 5
\end{tabular}

6. For how many meals/times a day did you use the stove?

7. Did you use less fuel wood? If so estimate with a percentage. $\%$

8. Do you think you saved any money? (YES or NO)

9. Estimate the actual amount of birr from the previous question. birr

10. Would you continue to use briquettes in the future? (YES or NO)

11. Would you purchase briquettes if they were made available for purchase? (YES or NO)

12. What do you like the most about the briquettes?

13. What do you like the least about the briquettes?

14. How much would you be willing to pay for four briquettes? birr 
15. Would you recommend the briquettes to friends?

(YES or NO)

16. Would you be willing to participate in future studies?

(YES or NO)

Household Data:

1. How many people are in the household?

2. Children under 16 Adult males, $16+$

Adult women, $16+$

3. Have you been involved with fuelwood or stove studies before? ( YES or NO)

4. Where do you get your fuelwood from? Purchased in Market? Cut locally? Home plantation?

5. Which member/s of the household collect or purchase the wood?

6. How many days a week do you purchase fuelwood?

7. Beginning fuelwood weight $\mathrm{kg}$

8. Ending fuelwood weight $\mathrm{kg}$ 


\section{Appendix 3}

\section{Briquette Survey 2 \\ Qu'achuu xuubii boba'aa laamaa}

Kebele:

Woreda:

Date:

Survey Questions:

2. Of the cooking methods you used briquettes with, how easy did you find each to light on a scale of $1-5$, with 1 being impossible and 5 being easy?

\begin{tabular}{|c|lllll|}
\hline Midijja & 1 & 2 & 3 & 4 & 5 \\
\hline Dhagaa sadii & 1 & 2 & 3 & 4 & 5 \\
\hline Berhanu & 1 & 2 & 3 & 4 & 5 \\
\hline
\end{tabular}

3. Once lit which was the easiest to keep burning? Rate on a scale of 1 to 5 , with 1 being that it could not be kept lit and 5 being the easiest to keep burning.

\begin{tabular}{|c|lllll|}
\hline Midijja & 1 & 2 & 3 & 4 & 5 \\
\hline Dhagaa sadii & 1 & 2 & 3 & 4 & 5 \\
\hline Berhanu & 1 & 2 & 3 & 4 & 5 \\
\hline
\end{tabular}

3. For each cooking method rate the following on the 1 - 5 scale. 1 being no smoke and 5 being the most. Circle one.

Amount of smoke produced

\begin{tabular}{|c|lllll|}
\hline Midijja & 1 & 2 & 3 & 4 & 5 \\
\hline Dhagaa sadii & 1 & 2 & 3 & 4 & 5 \\
\hline Berhanu & 1 & 2 & 3 & 4 & 5 \\
\hline
\end{tabular}


Length of one briquettes burn

\begin{tabular}{|c|lllll|}
\hline Midijja & 1 & 2 & 3 & 4 & 5 \\
\hline Dhagaa sadii & 1 & 2 & 3 & 4 & 5 \\
\hline Berhanu & 1 & 2 & 3 & 4 & 5 \\
\hline
\end{tabular}

17. How would you rate the briquettes overall performance on a scale of 1 $-5,1$ being the worst performance and 5 being the best.

\begin{tabular}{|lllll|}
\hline 1 & 2 & 3 & 4 & 5 \\
\hline
\end{tabular}

5. Do you feel the using the stove had any effect on the briquettes performance, positive or negative? if so, to what degree on the scale of 1 to 5 , with 1 being the least amount of effect and 5 the greatest amount.

\begin{tabular}{|lllll|}
\hline 1 & 2 & 3 & 4 & 5 \\
\hline
\end{tabular}

6. Which cooking method do you feel the briquettes are best and least suited for? Rate them 1 to 3 with 1 being the worst and 3 being the best.

\begin{tabular}{|c|c|}
\hline Midijja & \\
\hline Dhagaa sadii & \\
\hline Berhanu & \\
\hline
\end{tabular}

7. For how many meals/times a day did you use the stove?

8. Did you use less fuel wood? If so estimate with a percentage. $\%$

9. Do you think you saved any money? ( YES or NO)

10. Estimate the actual amount of birr from the previous question. birr 
11. Would you continue to use briquettes in the future?

( YES or NO)

12. Would you purchase briquettes if they were made available for purchase? (YES or NO)

13. What do you like the most about the briquettes?

14. What do you like the least about the briquettes?

15. What do you like the most about the new stove?

16. What do you like the least about the new stove?

17. How much would you be willing to pay for four briquettes? birr

18. What would be a fair price for the stoves? birr

19. Would you recommend the briquettes to friends?

( YES or NO)

20. Would you be willing to participate in future studies?

( YES or NO)

\section{Household Data:}

1. How many people are in the household?

2. Children under 16 Adult males, $16+$ Adult women, $16+$

3. Have you been involved with fuelwood or stove studies before? ( YES or NO) 
4. Where do you get your fuelwood from? Purchased in Market? Cut locally? Home plantation?

5. Which member/s of the household collect or purchase the wood?

6. How many days a week do you purchase fuelwood?

7. Beginning fuelwood weight

8. Ending fuelwood weight $\mathrm{kg}$ $\mathrm{kg}$ 